\title{
Building Retrofitting through Coupling of Building Energy Simulation-Optimization Tool with CFD and Daylight Programs
}

\author{
Mehrdad Rabani ${ }^{1,2, *}$, Habtamu Bayera Madessa ${ }^{1}$ and Natasa Nord ${ }^{2}$ (D) \\ 1 Department of Civil Engineering and Energy Technology, Oslo Metropolitan University, 0130 Oslo, Norway; \\ habama@oslomet.no \\ 2 Department of Energy and Process Engineering, Norwegian University of Science and Technology, \\ 7491 Trondheim, Norway; natasa.nord@ntnu.no \\ * Correspondence: mehrab@oslomet.no
}

Citation: Rabani, M.; Bayera Madessa, H.; Nord, N. Building Retrofitting through Coupling of Building Energy SimulationOptimization Tool with CFD and Daylight Programs. Energies 2021, 14, 2180. https://doi.org/10.3390/ en14082180

Academic Editor: Darya Nemova

Received: 18 March 2021

Accepted: 12 April 2021

Published: 14 April 2021

Publisher's Note: MDPI stays neutral with regard to jurisdictional claims in published maps and institutional affiliations.

Copyright: (c) 2021 by the authors. Licensee MDPI, Basel, Switzerland. This article is an open access article distributed under the terms and conditions of the Creative Commons Attribution (CC BY) license (https:// creativecommons.org/licenses/by/ $4.0 /)$.

\begin{abstract}
Simultaneous satisfaction of both thermal and visual comfort in buildings may be a challenging task. Therefore, this paper suggests a comprehensive framework for the building energy optimization process integrating computational fluid dynamics (CFD) daylight simulations. A building energy simulation tool, IDA Indoor Climate and Energy (IDA-ICE), was coupled with three open-source tools including GenOpt, OpenFOAM, and Radiance. In the optimization phase, several design variables i.e., building envelope properties, fenestration parameters, and Heating, Ventilation and Air-Conditioning (HVAC) system set points, were selected to minimize the total building energy use and simultaneously improve thermal and visual comfort. Two different scenarios were investigated for retrofitting of a generic office building located in Oslo, Norway. In the first scenario a constant air volume (CAV) ventilation system with a local radiator in each zone was used, while an all-air system equipped with a demand control ventilation (DCV) was applied in the second scenario. Findings showed that, compared to the reference design, significant reduction of total building energy use, around $77 \%$ and $79 \%$ in the first and second scenarios, was achieved respectively, and thermal and visual comfort conditions were also improved considerably. However, the overall thermal and visual comfort satisfactions were higher when all-air system was applied.
\end{abstract}

Keywords: building retrofitting; building performance optimization; CFD; daylight analysis; thermal and visual comfort

\section{Introduction}

It is estimated that building stock accounts for approximately $28 \%$, on a global scale [1], and $40 \%$, in the European Union, of total energy use [2]. Therefore, retrofitting existing buildings is considered as a crucial step to reach energy goals and to thoroughly decarbonize the building stock in Europe by 2050 [3]. A tailored approach in this respect applies building performance optimization techniques by using optimization algorithms to find the best set of retrofit measures based on simulation results and proposed objectives [4]. Many researchers, designers, and engineers have used this well-developed technique to improve building energy efficiency due to its capability in automating design tasks in various aspects in the last decade. These aspects concern four main elements, namely, objective functions, design variables, simulation, and optimization tools. Regarding objective functions, various parameters dealing with energy, visual, and acoustic performance of buildings are selected. For example, Djuric et al. [5], Rabani et al. [6], Karaguzel et al. [7], Chantrelle et al. [8] and Ferrara et al. [9] conducted a single objective optimization and considered the retrofitting costs or the building energy use (the two latter studies) as the objective. Several studies such as those of Mangnier and Haghighat [10], Harkouss et al. [11], Asadi et al. [12], Niemelä et al. [13], Wu et al. [14], Hamdy et al. [15], and Palonen et al. [16] 
conducted multi objective optimization to improve building performance. The objectives in the aforementioned studies dealt with building energy use, $\mathrm{CO}_{2}$ emissions, investment and operational costs, and thermal comfort indexes such as predicted percentage dissatisfied (PPD), predicted mean vote (PMV), and discomfort hours. In some studies, such as [17], the optimization objective was the improvement of renewable technologies such as minimizing the dependency on the nearby energy grid and maximizing the self-consumption of photo-voltaic (PV) panels. In addition to these objectives, several studies such as those of Zhang et al. [18], Kirimtat et al. [19], and Fang and Cho [20] focused mainly on daylight performance. In this regard, Naderi et al. [21] focused on the discomfort glare index (DGI) as the visual comfort indicator to be minimized. Some studies such as those of Bassuet et al. [22] and Saksela et al. [23] chose acoustic parameters as the objective function in the optimization process.

Most of the input design variables corresponded the building envelope and façade and service systems. For example, Chantrelle et al. [8], Grygierek and Ferdyn-Grygierek [24], Delgarm et al. [25], Schwartz et al. [26], and Harkouss et al. [11] optimized the window to wall ratio, façade U-values and thermal properties, roof topology, and glazing types. Djuric et al. [5], Mangnier and Haghighat [10], Delgarm et al. [27], Arabzadeh et al. [28], Bamdad et al. [29], and Lu et al. [30] focused on the set points for cooling and heating, supply air flow rates, solar collector and PV area and tilt angle, storage tank volume, the supply water temperature and the heat exchange area of the radiators as the input design variables. Operating strategies for heat storage and energy conversion techniques such as use of heat pump, solar panel, biomass, and oil boiler were optimized in the study by Wu et al. [14]. Furthermore, solar shading devices for windows were also optimized in terms of distance from glazing, movement point and rotation angle of panel, and the angle of louver blades $[19,31,32]$. Some research studies such as $[33,34]$ introduced a holistic platform so that the energy conservation measures (ECMs) and input design variables were not constrained to those to be applied at building level, but also considered district level measures. These sets of measures included: (1) passive ECMs relying on the increase of envelope thermal resistance or the current windows replacement, and upgrades of the façade, floor, roof, and openings; (2) renewable retrofitting strategies based on the installation of sustainable energy sources such as: wind, sun, water, and geothermal; (3) active ECMs including the replacement of existing energy supply systems by new ones such as biomass boilers, natural gas Combined Heat Power (CHP) units, and heat pumps; and (4) control ECMs which are related practically to the selected active ECMs such as system scheduling, optimal start-up and shut-down, weather compensation, load following, and sequencing control.

Until now, various tools and software packages have been developed for the optimization of building performance. With respect to building energy simulation (BES), EnergyPlus [7,25-27], TRNSYS [8,11,12,30], and IDA-ICE [13,15,28,35] were widely applied. Moreover, Radiance software was employed for daylight simulations in several studies [18-20]. Regarding optimization tools, several algorithms, software systems, and platforms have been commonly integrated with building performance tools. For example, GenOpt [5-7,29], MOO [31,36], GAMS [37], jEPlus [25-27], Rhinoceros [38], MATLAB [15,39,40], non-dominated sorting genetic algorithm II (NSGA II) $[13,28,35]$, and CPLEX algorithm [14,41] are among the widespread optimization tools and platforms. A recent study has shown that the integration of artificial neural networks such as Multilayer Feedforward Neural Networks (MFNN) with metaheuristic algorithms such as NSGA II and Multi-Objective Particle Swarm Optimization (MOPSO) can minimize the computation time [42].

Nevertheless, optimizing building energy performance using the aforementioned BES software still cannot ensure desirable indoor air conditions. The reason is that these software systems adopt a multi-zone approach to model the indoor airflow behavior in order to facilitate the implementation of simulation models and reduce the computational time [43]. In other words, each building zone in this approach is considered as a node with 
uniform distribution of temperature, humidity, concentration, etc. [44,45]. As the air is assumed to be well mixed in the zone, this method may not be effective and can fail to accurately predict the air flow behavior when a ventilation strategy functioning with a high vertical gradient (stratified) of air flow distribution is applied. This is important when controlling Heating, Ventilation, and Air-Conditioning (HVAC) systems for simulating thermal comfort distribution in the occupancy area [46].

Unlike the multi-zone modelling approach, the computational fluid dynamics (CFD) method has shown great potential in predicting indoor air flow behavior [47]. In this method, the building zone is divided into a large number of control volumes and NavierStokes equations are solved in these control volumes to precisely predict the air flow characteristics in the space [48]. Therefore, coupling BES software with the CFD method can improve the quality of results and provide detailed information about the thermal load, building energy use, spatial air temperature and thermal comfort distributions. There are two methods of coupling BES and CFD, namely one-step and two-step coupling; the first method only provides CFD with the boundary conditions obtained by BES, while the latter also returns the simulated boundary conditions from CFD to BES. In this regard, several researchers have investigated the coupling of BES and CFD.

Novoselac [49] developed a new tool for accurate analysis of building energy use and thermal comfort. Different coupling methods for exchanging data between BES and CFD were evaluated through a two-step method. It was found that delivering heat flux to CFD as boundary conditions and giving surface temperature back to BES can provide more accurate calculation of surface heat flux than log-law wall functions in CFD. Tian et al. [50] made a comprehensive review of the methods and applications of integrating CFD with BES. They compared different one-step and two-step methods in terms of limitations, accuracy, stability, convergence, and speed for the co-simulation. Rodríguez-Vázquez et al. [51] reviewed the research studies in which BES-CFD coupling was used to investigate building systems, building components, and urban configurations of buildings. Their findings show that the integration of the BES and CFD methods provides an improvement that ranges between $10 \%$ and $50 \%$ for predicting building energy requirements. Furthermore, the analysis showed that the computation time for implementing the CFD method could be reduced by importing the information from the BES. Shan et al. [52] coupled EnergyPlus for BES with FLUENT software for CFD simulation of air temperature and PMV field. Furthermore, the air flow rates across the virtual partition walls between two adjacent subzones obtained from CFD were given to EnergyPlus for use as inter-zone air flow. The aim was to find the optimal temperature set points for the subzones in order to achieve a uniform occupant thermal comfort and avoid overcooling in a large open office. Pandey et al. [53] also coupled the EnergyPlus and Ansys Fluent tools for BES-CFD simulations of phase change material (PCM) in the built environment and compared the results with those obtained from EnergyPlus. Their findings highlighted that the coupled simulation has better prediction accuracy than the BES tool for active and passive use of PCM under forced convection. However, the BES tool is recommended for modeling the passive use of PCM during natural convection. Yamamoto et al. [54] developed a coupling two-step method combining BES and CFD. The aim was to assess the accuracy of coupling by analyzing the obtained temperature distribution in an environment where natural convection by floor heating is dominant. Colombo et al. [55] considered the application of coupling the thermal network, using IDA-ICE software, with an external CFD tool, using Star-CCM+ tool, for a double-skin glazed façade over a warm day cycle. In their iterative process, the surface temperatures obtained from the BES tool were used as boundary conditions for the CFD simulation and the heat fluxes to and from the façade components computed by CFD were used to improve the BES tool estimation. Zhang and Mirzaei [56] proposed a new framework to substantially reduce the computation cost of the dynamic coupling procedure of CFD and BES. In their approach, a high-resolution CFD model $\left(\mathrm{CFD}_{\mathrm{f}}\right)$ provides the boundary conditions, including the flow patterns, to a low-resolution CFD model $\left(\mathrm{CFD}_{\mathrm{C}}\right)$ at the 
openings in the form of the mass flow information to BES, in order to start the iterative process. Afterwards, the $\mathrm{CFD}_{\mathrm{c}}$ and BES domains implement a fully dynamic external coupling to deliver an accurate energy simulation.

The optimization of building energy performance, by integrating different optimization and BES tools, to achieve a nearly zero energy building (nZEB) level has been extensively investigated in the literature, but only a few studies have considered the coupling of optimization, BES tool, and CFD software. In this paper, an inclusive methodology is introduced to couple the BES software, IDA-ICE [57], to the optimization tool, GenOpt, and the CFD software, OpenFOAM [58] (integrated in IDA-ICE), in order to reach a nZEB level with satisfactory thermal and visual comfort conditions. In the optimization process, both energy and daylight simulations were implemented simultaneously. Furthermore, a detailed post-analysis of thermal and visual comfort was performed through detailed CFD and dynamic daylight simulations.

\section{Methodology}

Figure 1 shows the coupling of optimization and CFD simulation framework.

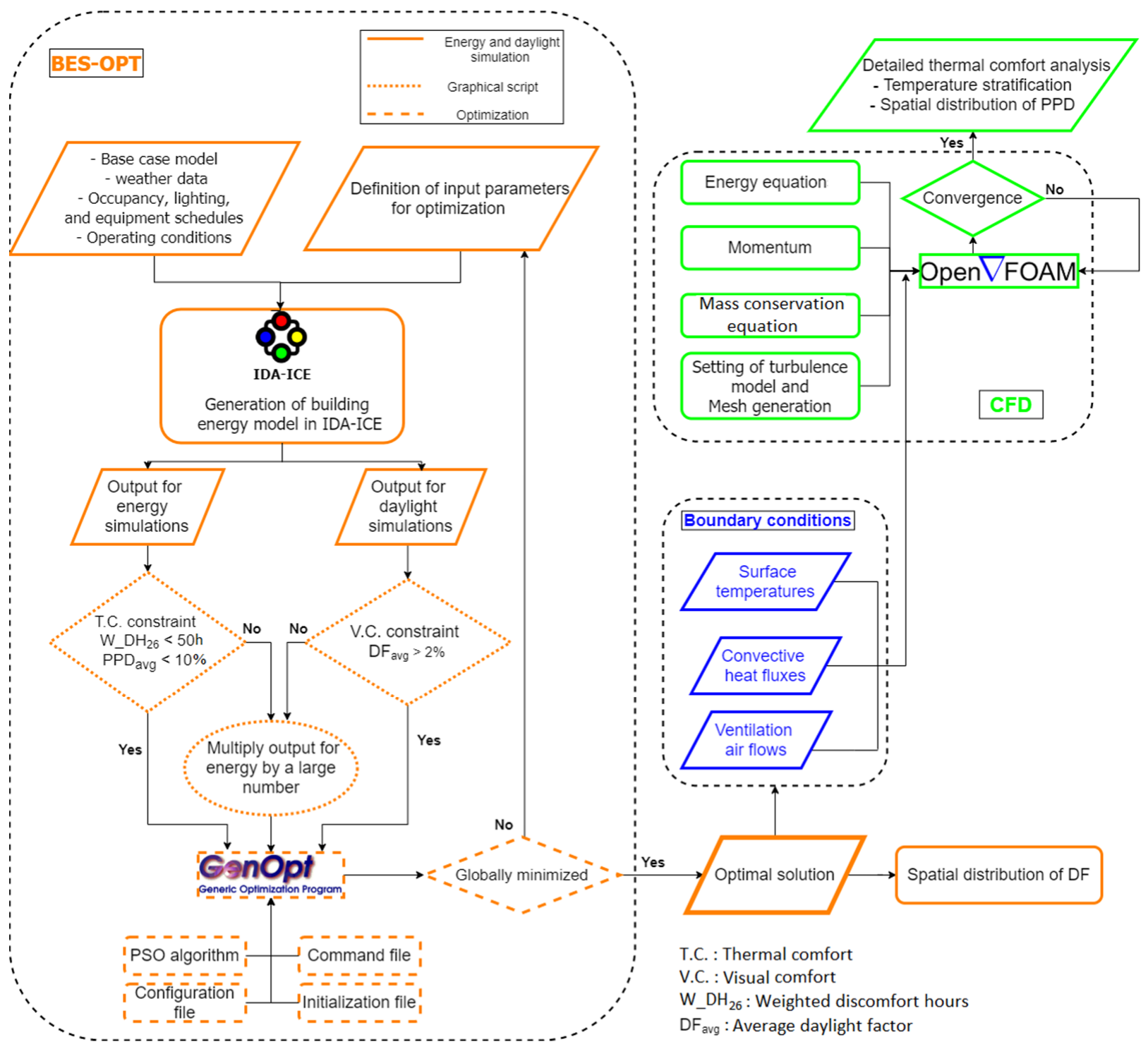

Figure 1. Building energy optimization, daylight, and computational fluid dynamics (CFD) framework. 
In the first step, the reference building model was generated in IDA-ICE and the optimization input parameters for daylight and energy simulations were described in the building energy simulation-optimization process (BES-OPT). The obtained results from both simulation types were evaluated in terms of average daylight factor $\left(\mathrm{DF}_{\mathrm{avg}}\right)$, discomfort hours $\left(\mathrm{DH}_{26}\right)$, and average predicted percentage of dissatisfied ( $\left.\mathrm{PPD}_{\mathrm{avg}}\right)$ through Graphical Script (GS) interface in IDA-ICE. Afterwards, the simulation results were transferred to the optimization tool to iteratively assess the objective function until an optimal solution was reached. Finally, a post-processing step analyzed the optimal solutions in detail in terms of thermal comfort and daylight quality using the CFD and detailed daylight simulations.

\subsection{BES-OPT Process}

In this stage, the reference building energy model was first generated using IDA-ICE software (solid orange objects in Figure 1). This was a typical office building located in Norway. The total heated floor area of the building was selected at around $3000 \mathrm{~m}^{2}$ as the majority of office buildings were constructed in the 1980s with a total heated floor area of between 2500 to $10,000 \mathrm{~m}^{2}$ [59]. The building envelope properties, technical system specifications and set points were chosen for a general office building constructed in 1987 meeting the Norwegian building code TEK87 [60], as explained in our previous work [61].

The optimization process was implemented by coupling IDA-ICE software with a GS interface and GenOpt tool. GS interface is an available option in IDA-ICE (dotted orange objects in Figure 1) considered as an intermediate step to manipulate the outputs from IDA-ICE regarding the thermal and visual comfort constraints. Details of GS interface functions can be found in the work done by Rabani et al. [6].

Regarding optimization scenarios, two different cases were considered. In the first case, it was assumed that the space heating and ventilation systems remained as the same type as the reference building and in the second scenario, an all-air system was used instead. An all-air system means that the ventilation, space heating and cooling in different zones were performed using a demand control ventilation (DCV) system without applying any means of local heating or cooling units, e.g., a radiator, in the zones. Therefore, two different set of parameters were considered as the optimization input variables. However, the input parameters corresponding to glazing and building envelope, shading device and window opening control methods, and shading materials and lighting rates were common input variables for both scenarios. The common parameters were as follows:

- Window-to-floor ratio (\%): the ratio of window-to-floor varied in the range of 10-24\% with a $2.8 \%$ interval. To alter the size of all the windows with a correct coordinate at the same time as the ratio was changed, a coordinate calculator was developed through GS in IDA-ICE.

- Window U-values $\mathrm{W} /\left(\mathrm{m}^{2} \cdot \mathrm{K}\right)$ : the values were changed from 0.6 (based on Norwegian building code TEK87) to 2.4 (based on Norwegian passive standard for non-residential buildings NS 3701) with an interval of 0.2 [62]. It should be noted that better window U-values are also associated with shifting from single glazed to triple glazed windows, which results in higher investment cost.

- Roof U-values $\mathrm{W} /\left(\mathrm{m}^{2} \cdot \mathrm{K}\right)$ : the values were improved from U-value 0.2 to U-value 0.06 by adding an EPS S80 insulation layer increasing from a thickness of $180 \mathrm{~mm}$ to $620 \mathrm{~mm}$, respectively.

- $\quad$ External wall U-values $\mathrm{W} /\left(\mathrm{m}^{2} \cdot \mathrm{K}\right)$ : the values were improved by adding Mineral Wool insulation layer, from a thickness of $30 \mathrm{~mm}$, corresponding to U-value 0.3 , to $280 \mathrm{~mm}$, corresponding to U-value 0.1 .

- Window opening control method: three opening control methods included closed windows, seasonal opening with temperature and $\mathrm{CO}_{2}$ control, and opening with temperature, wind velocity, and solar radiation control. Details of window opening control methods are elaborated in our previous work [61]. 
- $\quad$ Shading device control method: seven control methods were considered. The main parameters in these control methods were solar radiation, daylight level, and indoor operative temperature. The performance of these control methods was elaborated in our previous work. Details of shading control methods are also explained in our previous work [61].

- Heat exchanger efficiency in (air handling unit) AHU: three values 0.55, 0.75, and 0.85 were considered.

- $\quad$ Shading materials: Generic outside, Marine, Celery, Pewter, Mocha, Bisque, and White venetian blind slats as well as Opaque white colored and light-dark colored slats were selected for the slats of the integrated window shading [61].

- $\quad$ Lighting rate $\left(\mathrm{W} / \mathrm{m}^{2}\right)$ : three lighting rates 7,11 , and $30 \mathrm{~W} / \mathrm{m}^{2}$ were selected.

- Supply air temperature profile in the AHU: the profile was considered as a function of outdoor temperature and was described at four points, shown in Table 1.

Table 1. Supply air temperature profile in the air handling unit (AHU) in both scenarios.

\begin{tabular}{ccc}
\hline Point Number in the Profile & Range-Interval $\left({ }^{\circ} \mathbf{C}\right)$ & $\begin{array}{c}\text { Corresponding Outdoor } \\
\text { Temperature }\left({ }^{\circ} \mathbf{C}\right)\end{array}$ \\
\hline 1st point & $(16-30)-1.6$ & -20 \\
2nd point & $(16-30)-1.6$ & -15 \\
3rd point & $(13-22)-1.6$ & 10 \\
4th point & $(13-22)-1.6$ & 35 \\
\hline
\end{tabular}

The parameters used only in the first optimization scenario (CAV) were the followings:

- Supply hot water temperature profile for radiators used for space heating: the profile was described in the same manner as the supply air temperature in AHU, shown in Table 2.

Table 2. Supply hot water temperature profile for space heating from central heating system in the first scenario.

\begin{tabular}{ccc}
\hline Point Number in the Profile & Range-Interval $\left({ }^{\circ} \mathbf{C}\right)$ & $\begin{array}{c}\text { Corresponding Outdoor } \\
\text { Temperature }\left({ }^{\circ} \mathbf{C}\right)\end{array}$ \\
\hline 1st point & $(45-90)-1.6$ & -31 \\
2nd point & $(45-90)-1.6$ & -26 \\
3rd point & $(25-60)-1.6$ & 20 \\
4th point & $(14-40)-1.6$ & 25 \\
\hline
\end{tabular}

- Supply/return water temperature to/from radiators: 16 combinations of four supply temperature set points $45,55,65,70\left({ }^{\circ} \mathrm{C}\right)$ and return temperature set points $25,30,35$, $40\left({ }^{\circ} \mathrm{C}\right)$.

- Upper/lower limit of ventilation supply airflow rate during heating and cooling seasons. Five profiles for heating season and eight profiles for cooling season, illustrated in Figure 2. 

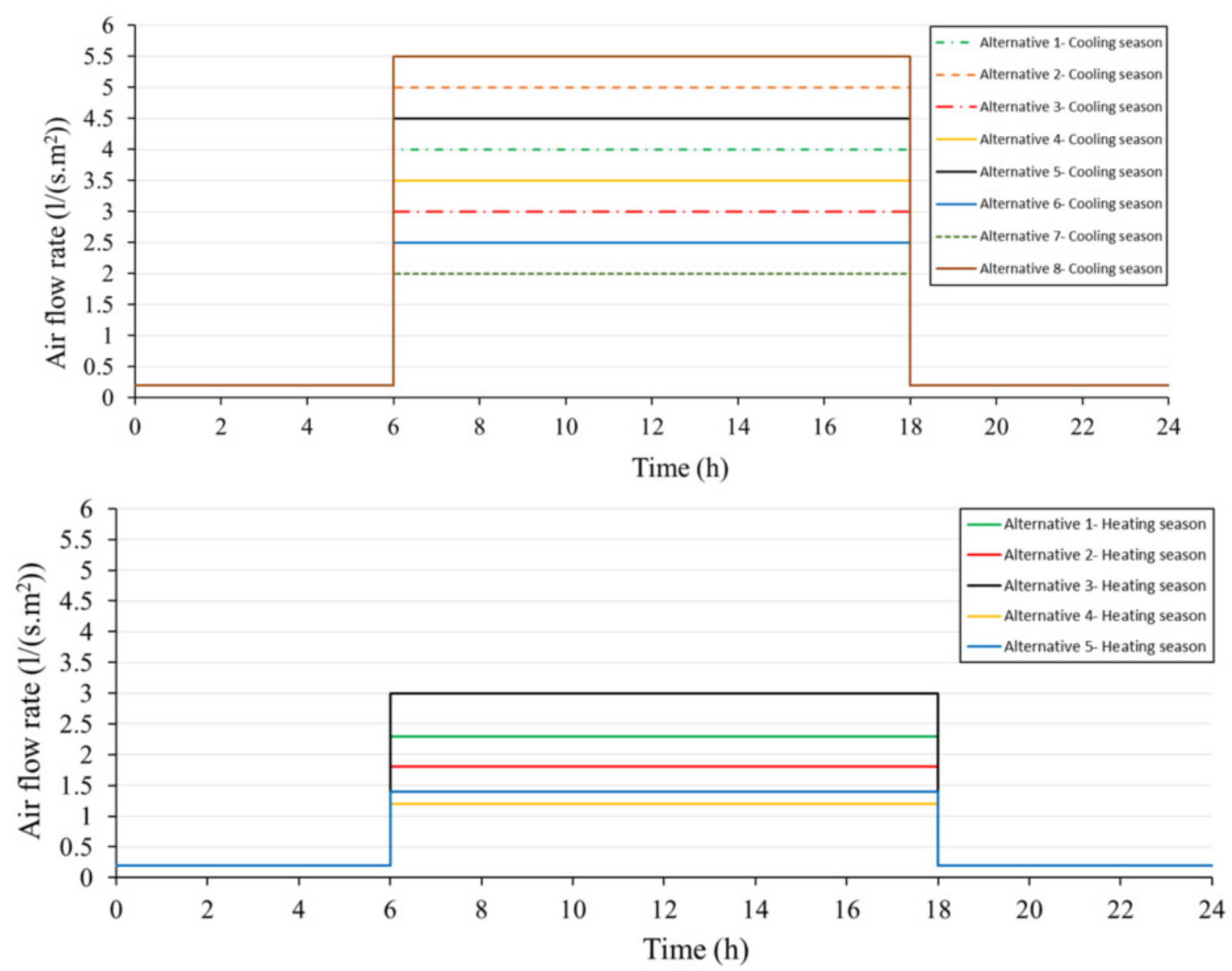

Figure 2. Ventilation air flow rates for cooling (top) and heating (bottom) seasons in the first optimization scenario. follows:

The parameters used only in the second optimization scenario (all-air system) were as

- $\quad$ Type of DCV system: four types of airflow control listed in Table 3.

Table 3. Various types of control method for DCV system in the second scenario.

\section{System Type}

Variable air volume with humidity control

Variable air volume with $\mathrm{CO}_{2}$ control

Variable air volume with temperature control

Variable air volume with temperature and $\mathrm{CO}_{2}$ control

\section{Control Method}

Maximum relative humidity set point: $60 \%$ for cooling season and $40 \%$ for heating season ${ }^{1}$

Minimum relative humidity set point: $20 \%$ for both cooling and heating seasons ${ }^{1}$

Maximum $\mathrm{CO}_{2}$ set point: $1100 \mathrm{ppm}$

Minimum $\mathrm{CO}_{2}$ set point: $700 \mathrm{ppm}$

Maximum temperature set point: $26^{\circ} \mathrm{C}$

Minimum temperature set point: $19^{\circ} \mathrm{C}$ Combination set points for $\mathrm{CO}_{2}$ and temperature

${ }^{1}$ There is no specific limit value for humidity of indoor air in Norway, only recommendations to prevent dampness and mold growth [63,64].

Maximum air flow rate set point: the air flow rate varied between 2 to $6 \mathrm{~L} /\left(\mathrm{s} . \mathrm{m}^{2}\right)$ with interval $0.27 \mathrm{~L} /\left(\mathrm{s} . \mathrm{m}^{2}\right)$.

The objective of the optimization process was to minimize the total delivered energy to the building $\left(\mathrm{E}_{\mathrm{tot}}\right)$ meaning that the problem was a single objective optimization. The constraint parameters were visual comfort index, assessed using average daylight factor $\left(\mathrm{DF}_{\mathrm{avg}}\right)$, and thermal comfort indexes, evaluated using weighted average PPD (W_PPD avg) 
and weighted discomfort hours over $26^{\circ} \mathrm{C}\left(\mathrm{W}_{-} \mathrm{DH}_{26}\right)$ [61]. According to the current requirements for Norwegian building code TEK17 [65], the $\mathrm{DF}_{\text {avg }}$ was set greater than or equal to $2 \%$. Regarding the thermal comfort, building comfort category II [66] was considered stating that $\mathrm{W}_{-} \mathrm{PPD}_{\text {avg }}$ and $\mathrm{W} \_\mathrm{DH}_{26}$ should be less than $10 \%$ and $50 \mathrm{~h}$, respectively.

In the present study, the optimization Particle Swarm Optimization (PSO) algorithm was selected in GenOpt to deal with both continuous and discrete input parameters and benefit from the global features of the PSO algorithm [61,67]. Furthermore, both energy and daylight simulations were simultaneously carried out in IDA-ICE on 32 GB RAM of a Windows-based workstation $(2.20 \mathrm{GHz})$ with Intel (R) Xeon (R) Gold $5120 \mathrm{CPU}$ with 14 parallel cores, and lasted for around 40 days to finish each optimization case. Combinations of the input parameters were in total $1.07 \times 10^{18}$ cases. By using the optimization, a large number of simulation cases were reduced to only 1900 cases, using IDA-ICE software. Nevertheless, since both energy and daylight simulations were run for each case with complicated window opening and shading control methods, the computational time increased considerably.

\subsection{Boundary Conditions and CFD Process}

After finding the optimal solution, as the first step detailed CFD and daylight simulations were performed for optimal solutions to investigate thermal and visual comfort in further detail. The CFD simulations were done in IDA-ICE by interfacing with the OpenFOAM CFD engine, and the daylight simulations were performed through the Radiance program [68]. However, calculation setup and execution were performed in IDA-ICE for both CFD and daylight simulations.

Regarding the CFD process, the one-way approach was considered. Firstly, coupling of BES and CFD was validated by the available experimental data and our previous numerical study for a single office building [69,70], in which we used Star-CCM+ software for performing CFD simulations [69]. Afterwards, the coupling method was applied to the optimal solutions, as illustrated in Figure 1 (blue and green objects). In the coupling process, the required boundary conditions for CFD simulations including surface temperature, surface convective heat flux, and ventilation air flows were exported from the IDA-ICE to the OpenFOAM CFD engine. These boundary conditions were then used by the CFD program to solve the continuity, momentum, and energy equations. Moreover, for the CFD simulations, the steady state solver with the RNG k- $\varepsilon$ turbulence model were selected, as this model has been used extensively in the simulation of indoor air flow problems [71]. In accordance with the modelled geometry, a hexahedral mesh model was generated and executed in the CFD interface in IDA-ICE. Furthermore, a mesh refinement was applied to the boundary layers near the surfaces. The obtained indoor air velocity and air temperature results from the CFD simulations were then exported to the MATLAB program for PPD calculation.

Figure 3 shows a real office cubicle fitted with measuring devices and its corresponding 3DModel modelled in IDA-ICE, used for the validation study. The office was equipped with an active supply diffuser located on the ceiling for both space heating and ventilation purposes. The details of experimental conditions including room dimensions, location of supply and exhaust terminals on the ceiling, and supply air temperature and flow rate were reported in $[69,70]$. 

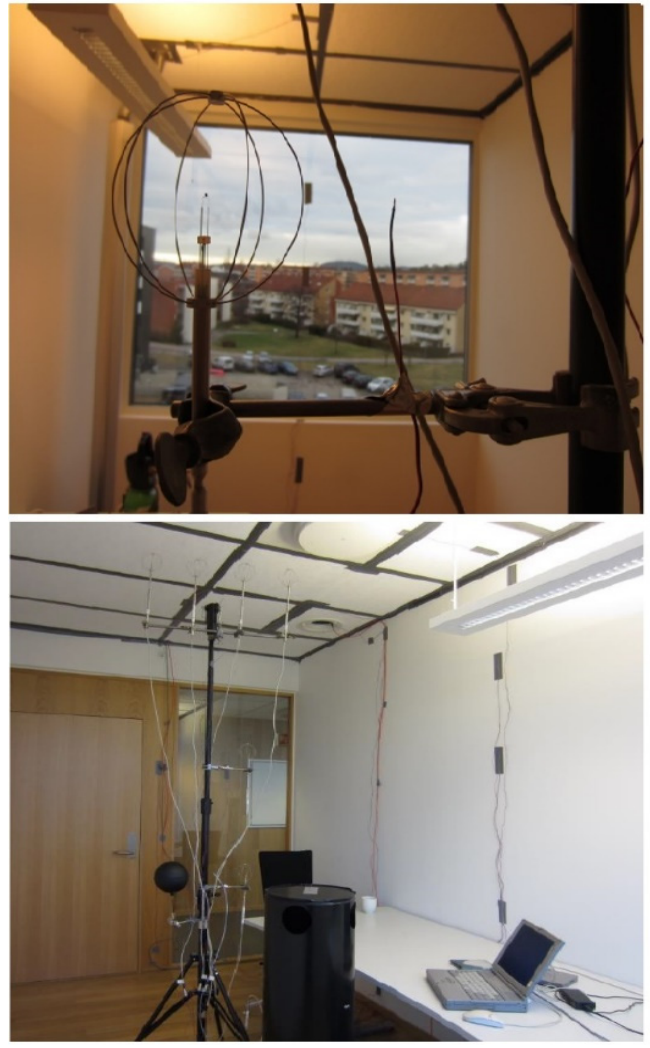

(a)
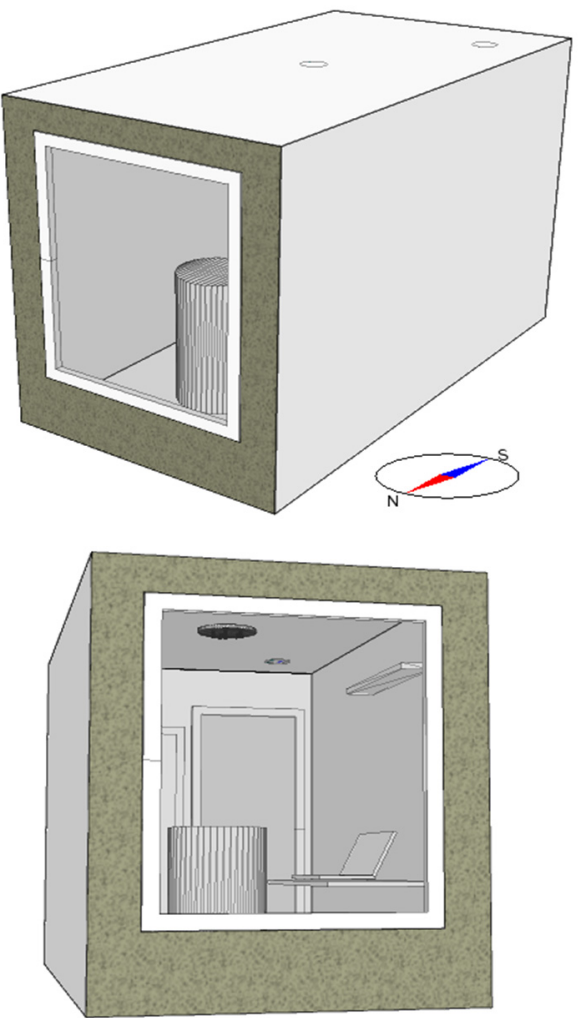

(b)

Figure 3. (a) Experimental setup [70] and (b) modelled configuration of the office cubicle in IDA-ICE.

\subsection{Daylight Analysis}

To obtain an overview of visual comfort throughout the year, three dynamic daylight indexes including Useful Daylight Illuminance (UDI), continuous Daylight Autonomy (cDA), and spatial Daylight Autonomy (sDA) were calculated (see Appendix A for details) and visualized for two optimization scenarios and the reference case. UDI describes how many hours or the percentage of the occupancy hours in which daylight levels are within the desired interval [72]. In this study, 100 lux and 2000 lux were selected as the minimum and maximum limits, respectively. cDA represents the percentage of the workhours when the illuminance is over or under a predefined threshold. In the present study, the percentage of daytime hours over 300 lux with partial credit was considered [73]. Furthermore, sDA shows the percentage of the occupied hours when the illuminance is equal or greater than 300 lux [74].

The daylight simulations were carried out through the Daylight-tab in IDA-ICE that uses backward raytracing and Radiance as a simulation engine. In this regard, a climatebased sky model with high precision was used in the Radiance software and a MATLAB script was used for visualizing the dynamic daylight indexes.

\section{Results and Discussion}

In this section, the results obtained from BES-OPT are presented for both scenarios. Afterwards, a detailed analysis of CFD and daylight simulations for the optimal solutions are described.

\subsection{BES-OPT Analysis}

Figure 4 shows the scatter plot of optimized results filtered by both thermal and visual comfort constraints. The triangles show the simulation cases where the discomfort hours were larger than 50 and the circles show those cases with discomfort hours smaller than 50. Furthermore, the dark symbols (both triangles and circles) represent the 
simulation cases with low total delivered energy to the building $\left(\mathrm{E}_{\text {tot }}\right)$ while those with higher $\mathrm{E}_{\text {tot }}$ are demonstrated with lighter colors. Comparing the first (Figure 4a) and the second (Figure $4 \mathrm{~b}$ ) scenarios shows that satisfying thermal comfort requirements was more difficult in the second scenario than in the first scenario during the optimization process, which can be observed by the larger number of triangles and larger range of W_PPD ${ }_{\text {avg }}$ in the second scenario. The reason could be the more complicated control method of space heating and the ventilation system in the second scenario as they both functioned with a supply air terminal in an all-air system. Therefore, it was more challenging to find a combination of set points for the ventilation system to minimize building energy use and achieve thermal comfort concurrently in the second scenario. On the contrary, the daylight factor requirement was satisfied for more cases in the second than in the first scenario which could be due to the shading control method and higher window-to-floor ratio in the second scenario.

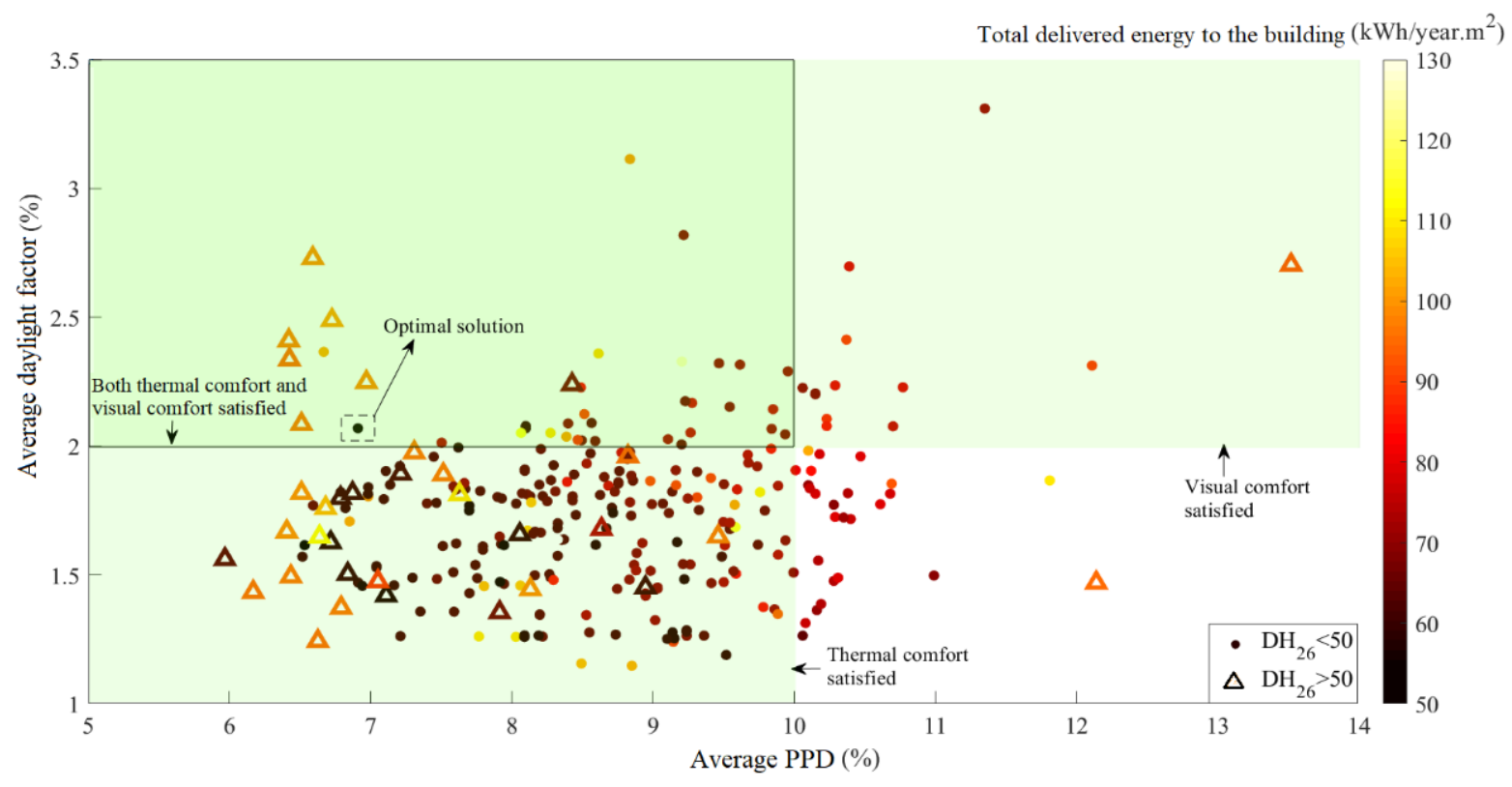

(a)

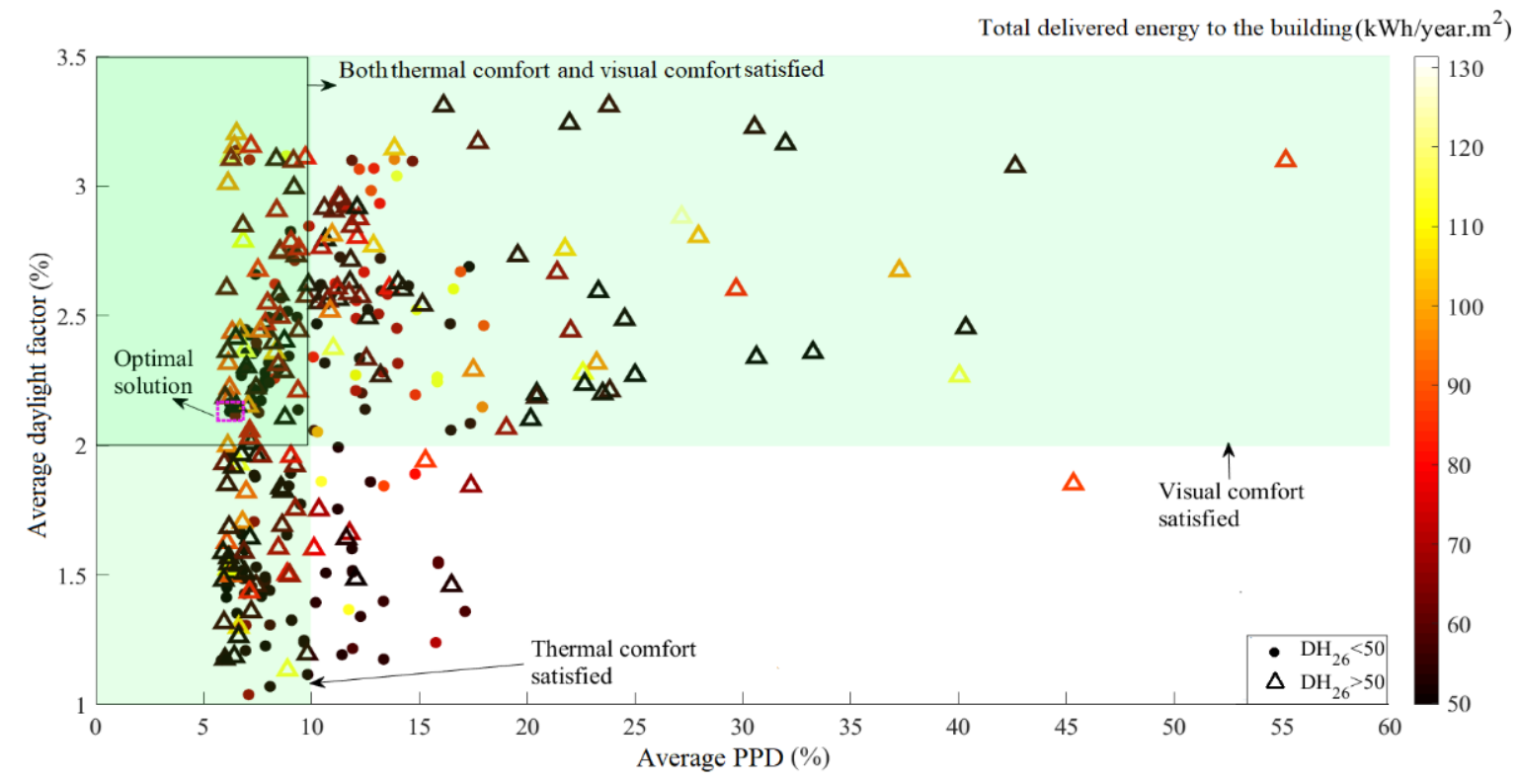

(b)

Figure 4. Optimization results for the first scenario (a) and the second scenario (b). 
The optimized input parameters for both scenarios are shown in Table 4. Different window-to-floor ratio, $U$-value of building envelope, and shading control methods were required to satisfy both thermal and visual comfort in both scenarios. As was also observed in Figure 4, satisfying thermal comfort, especially $\mathrm{DH}_{26}$, was more difficult in the second scenario than in the first. Thus, the best quality of window and external wall could not be selected in the second scenario as a tighter building envelope would result in larger $\mathrm{DH}_{26}$ and consequently reduce thermal comfort. The best performance and efficiency of the lighting system and heat exchanger were selected for both scenarios, as enhancing their efficiency could decrease the building's energy use with trivial impact on the visual and thermal comfort conditions.

The percentile distribution of delivered energy use to the building, filtered by either and then both thermal and visual comfort conditions, is shown in Figure 5 for all solutions. Adopting an all-air system in the second scenario could result in overall less energy use compared to the CAV system. In this regard, around $75 \%$ of the simulated cases had less energy use in the second scenario than the $50 \%$ in the first scenario. However, in both scenarios, the cases filtered only by thermal comfort could arrive at less energy use with less distribution than by visual comfort, implying that achieving low-level building energy use with thermal comfort is easier than with visual comfort. The reason is that the number of input parameters influencing visual comfort were fewer than for thermal comfort.

Table 4. Optimized input parameters for both scenarios.

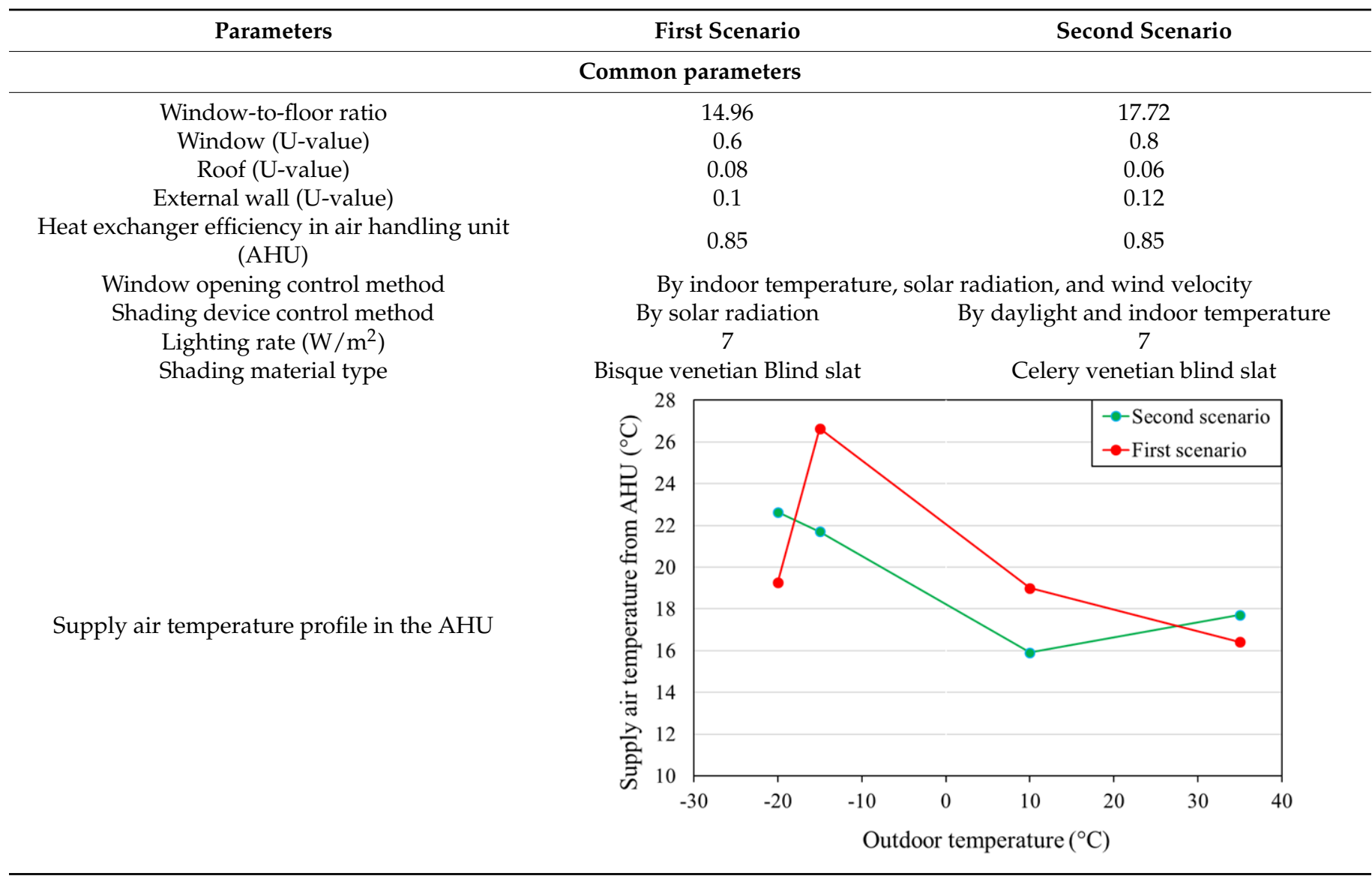


Table 4. Cont.

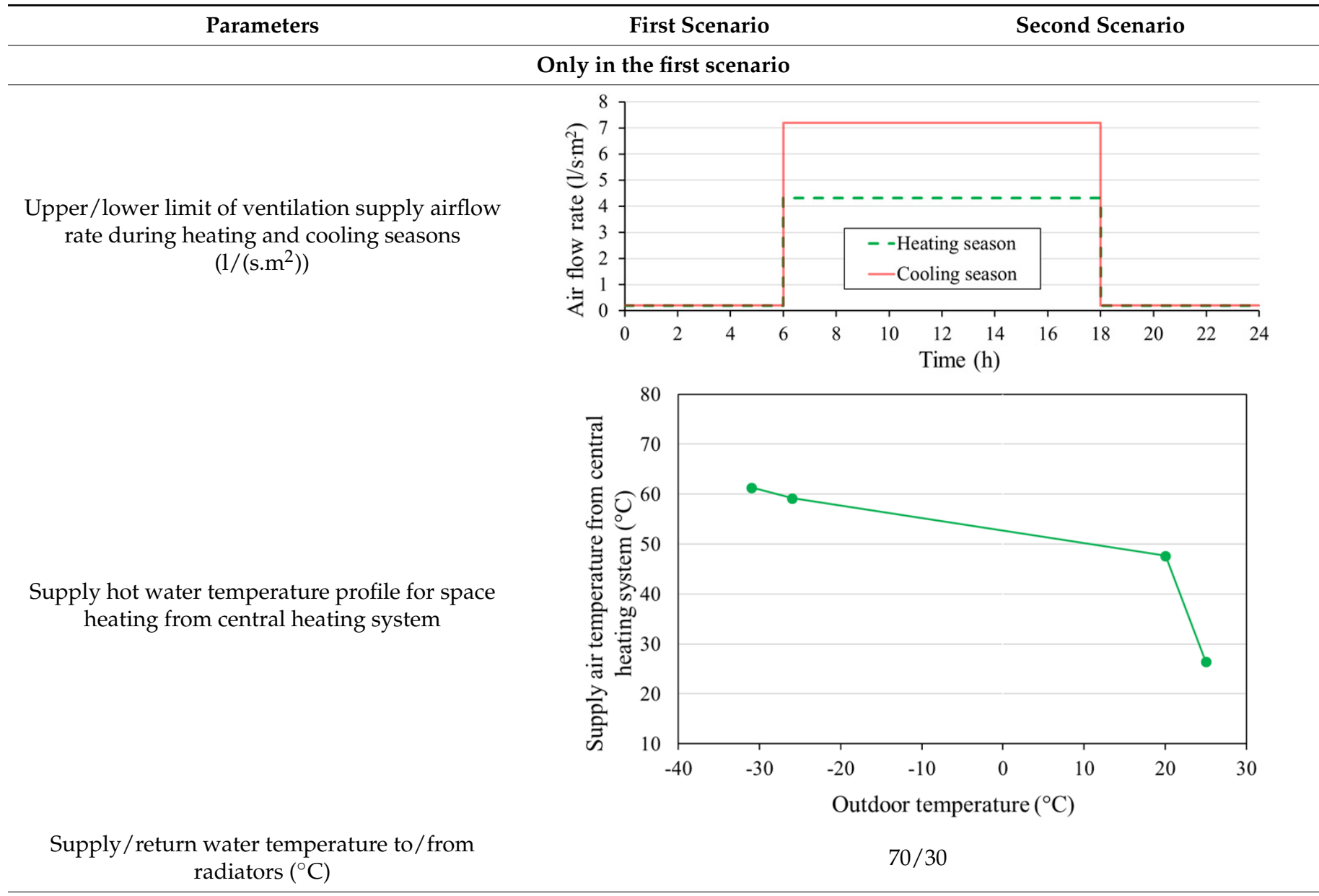

\section{Only in the second scenario}

Type of demand control ventilation (DCV) system

Variable air volume with temperature control

Maximum air flow rate set point $\left(1 / \mathrm{s}^{2} \mathrm{~m}^{2}\right)$

3.39

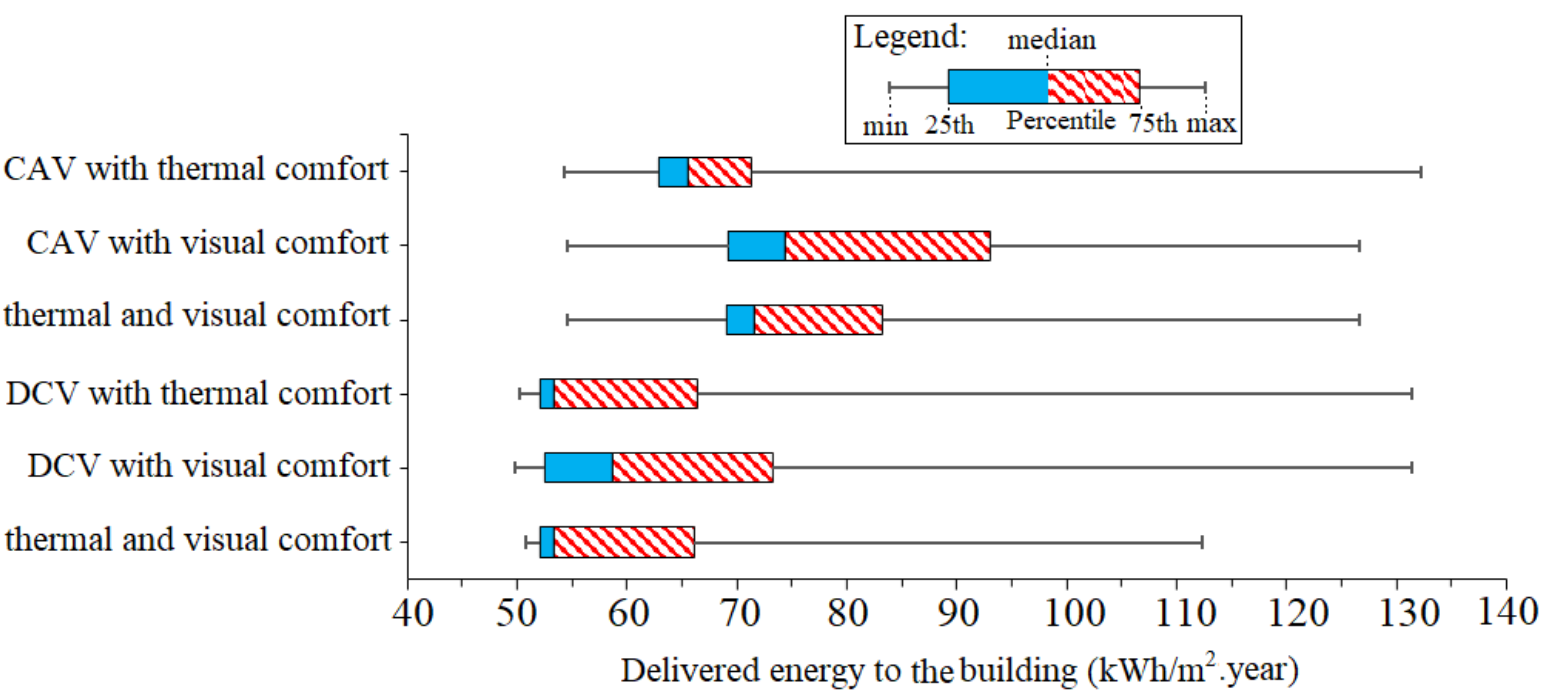

Figure 5. Percentile distribution of annual delivered energy to the building. 
Figure 6 shows the amount of delivered energy to the building for the reference case and two optimization scenarios. Optimizing the building performance could reduce building energy use by up to approximately $77 \%$ and $79 \%$ in the first and second scenarios, respectively, while satisfying both thermal and visual comfort. The reasons were better building envelope quality, appropriate window-to-floor ratio, and proper control methods for shading device and window opening that were selected through the optimization process in both scenarios. Less energy use in the second scenario than in the first could mainly be due to the type of ventilation in the all-air system, for which the DCV method could adjust the air flow rate according to the considered control parameters for indoor conditions (see Table 3). However, the CAV ventilation method in the first scenario maintained a constant air flow rate during working hours, disregarding indoor conditions. This proves that an all-air system can be considered as a potential HVAC system in cold climate countries as it can reduce the investment and maintenance costs associated with local space heating and cooling systems.

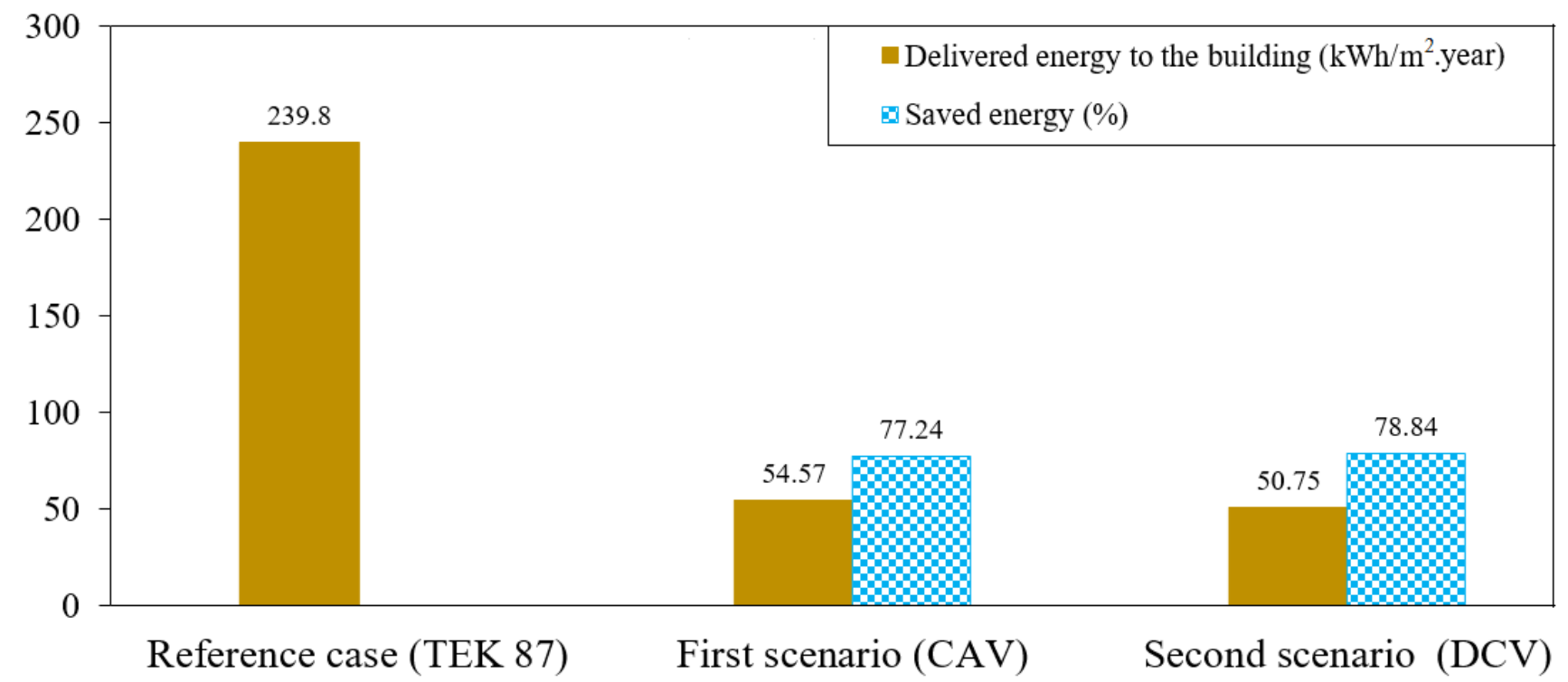

Figure 6. Delivered energy to the building for two optimization scenarios.

\subsection{CFD and Daylight Assessment}

Figure 7 shows the variation of indoor air temperature and air velocity along the measurement line in the vertical plane defined in the experimental work [70]. As can be seen, both temperature and velocity variations obtained in the present study were in good agreement with our previous numerical study and were also within the uncertainty range of the experimental data. The RNG k- $\varepsilon$ turbulence model, used in this study, and the Standard K- $\varepsilon$ model, used in our previous numerical study [69], indicated almost the same trend and followed the experimental data with good agreement, except in the proximity of the ceiling (Figure 7a). However, the RNG k- $\varepsilon$ turbulence model could predict air velocity better than the Standard K- $\varepsilon$ model near the floor, and followed the experimental data less well than Standard K- $\varepsilon$ at the middle height of the room (Figure $7 \mathrm{~b}$ ).

Figures 8 and 9 show, respectively, the annual variation of average PPD and spatial distribution of PPD for the worst zone, in terms of difficulty in meeting comfort conditions, for the reference case and two optimization scenarios. More precisely, the worst zone in this study was defined as the zone in the building experiencing the highest operative temperature in summer and largest temperature fluctuations throughout the year. The coldest day was 2nd January $\left(\mathrm{T}_{\text {outdoor }}=-19^{\circ} \mathrm{C}\right)$, and the warmest day was 1st August $\left(\mathrm{T}_{\text {outdoor }}=31^{\circ} \mathrm{C}\right)$, selected based on climate data for outdoor air temperature. Looking at the annual average variation of PPD, it is found that both optimized scenarios could satisfy the thermal comfort requirements, based on the comfort category II, for a longer period of 
the year compared to the reference case. The second optimized scenario showed the best performance in this respect. However, the all-air system (second optimized scenario) could not provide comfortable conditions, according to any of the thermal comfort categories, in January and December. This can also be observed in the spatial distribution of PPD on the coldest day, when a rather high degree of discomfort was experienced in the occupancy area (the black rectangle) in the second scenario (Figure 9c). On the warmest day, both optimized scenarios showed an acceptable performance in the occupancy area in spite of window opening. Although two optimized scenarios could not provide as acceptable thermal comfort conditions as the reference case on the coldest and warmest days, the annual thermal comfort was, in general, improved for both optimized scenarios. It should be pointed out that the improvement of thermal comfort was achieved along with the reduction of delivered energy to the building by more than $77 \%$.

To examine the uniformity of air temperature distribution and the possibility of temperature stratification, the distribution of vertical air temperature difference for CFD cells between the ankle level $(0.1 \mathrm{~m}$ above the floor) and the head level $(1.1 \mathrm{~m}$ for a seated person), in the occupancy area, is shown in Figure 10. The occupancy area was defined as the area $0.6 \mathrm{~m}$ from the side walls and from $0.1 \mathrm{~m}$ to $1.8 \mathrm{~m}$ above the floor. On the coldest day of the year (Figure 10), the majority of points met the requirements for vertical air temperature difference, which is less than $3 \mathrm{~K}$ according to the second thermal comfort category for office buildings [75]; however, a slight temperature stratification was observed covering around $50 \%$ of the occupancy area at the second scenario on the morning of the coldest day of the year. This could be due to considering yearly average PPD as the thermal comfort constraint during optimization. In addition, with respect to Figures $8 c$, $9 \mathrm{c}$ and 10 , it can be implied that a different control method for the DCV system should be adopted in the coldest periods of the year. Nevertheless, the window opening was functional for both optimized scenarios during summertime and no significant temperature stratification was observed, despite using a rather low air flow rate compared to the reference case.

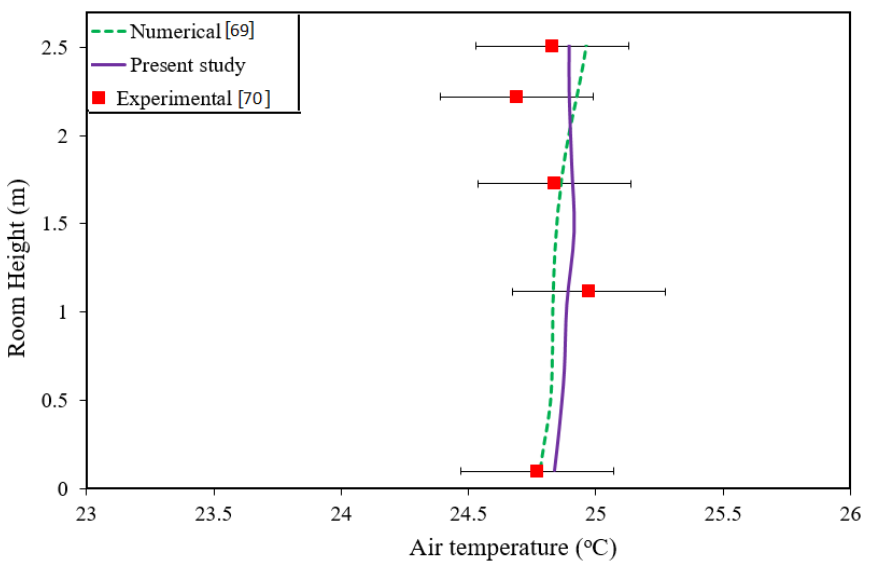

(a)

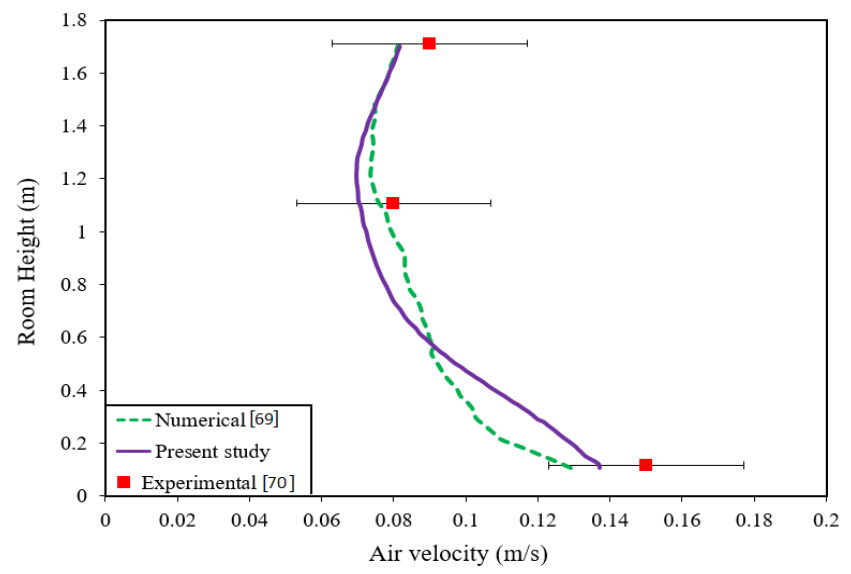

(b)

Figure 7. Variation of (a) air temperature and (b) air velocity in the validation study. 
(a)

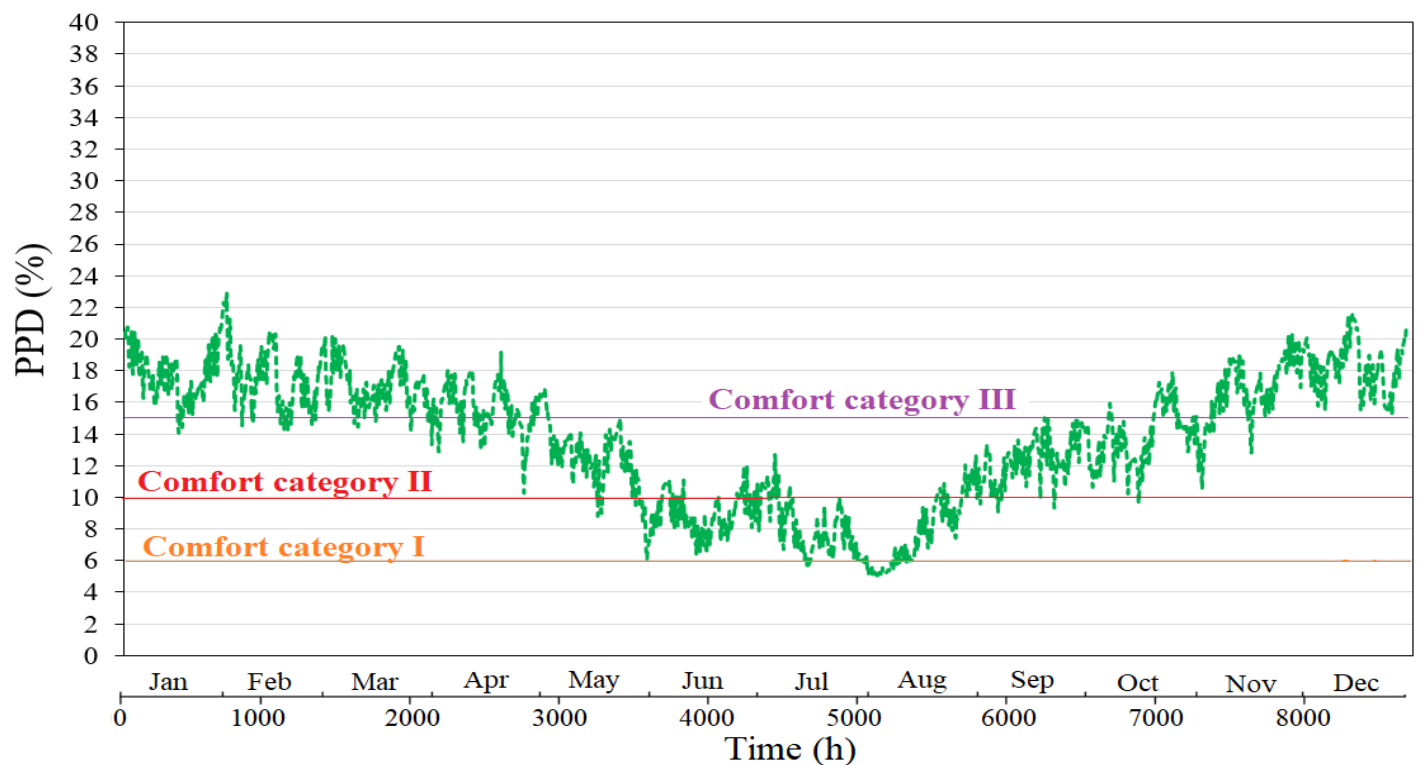

(b)

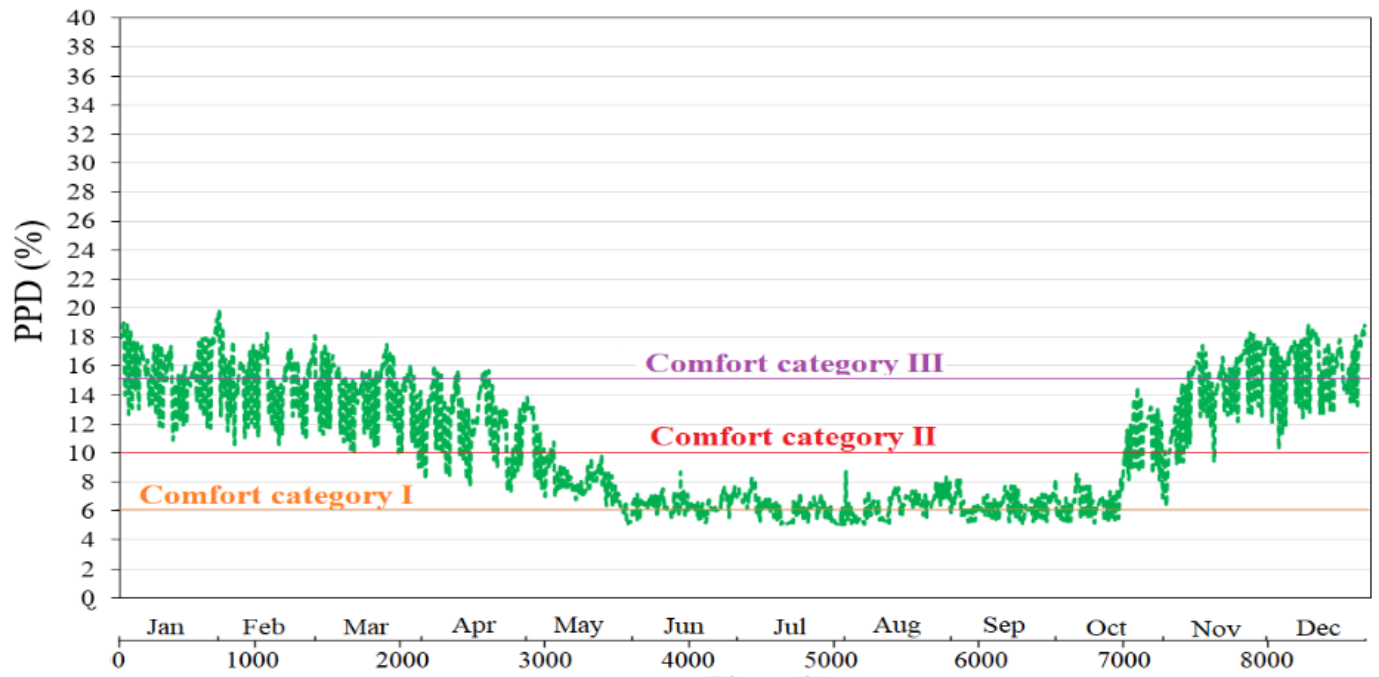

Time (h)

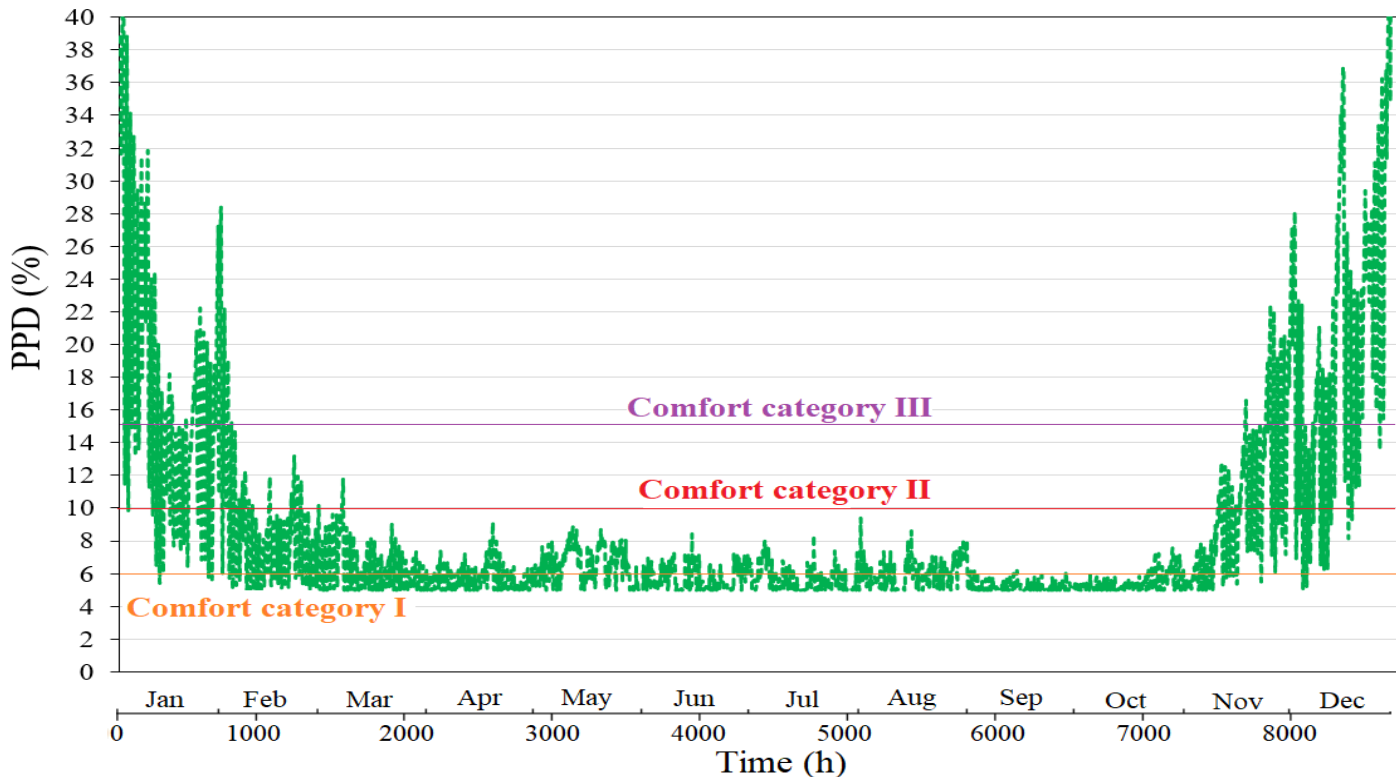

Figure 8. Annual variation of average predicted percentage dissatisfied (PPD) for the cell office C.O.16 for the (a) reference case, (b) first optimized scenario (c) second optimized scenario. 


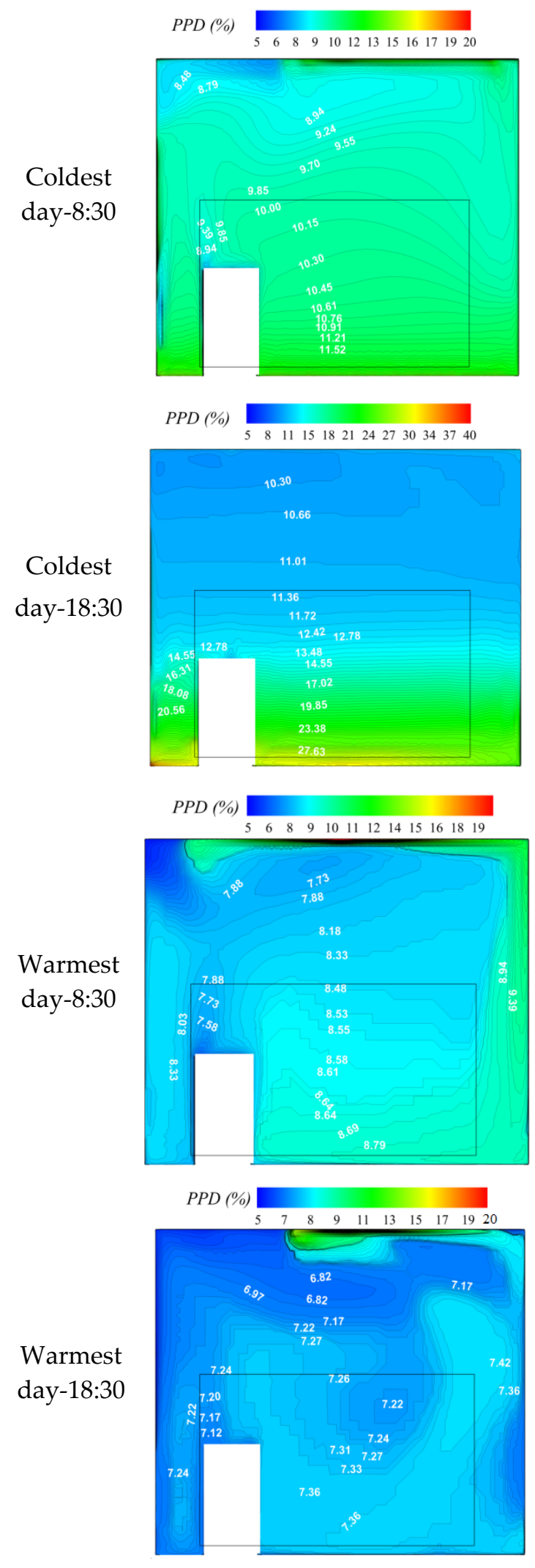

(a)

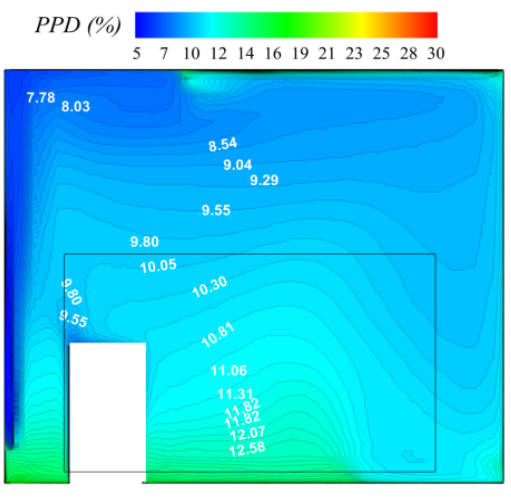

PPD (\%)
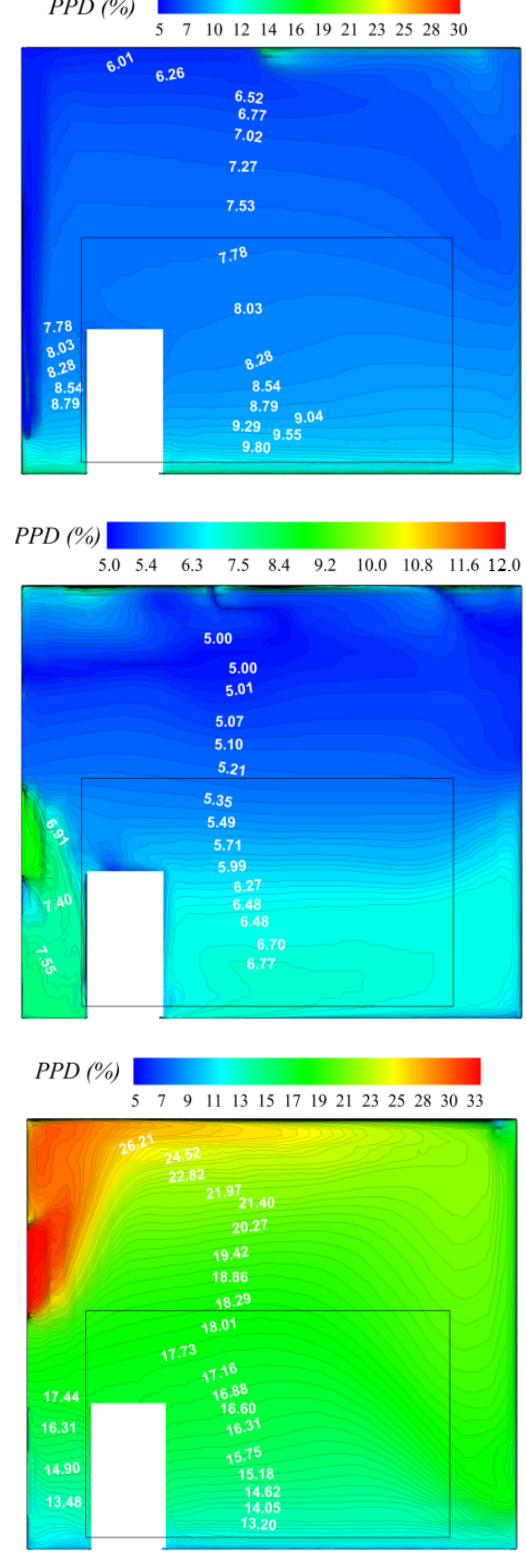

(b)
PPD (\%) 131620232630333740434750
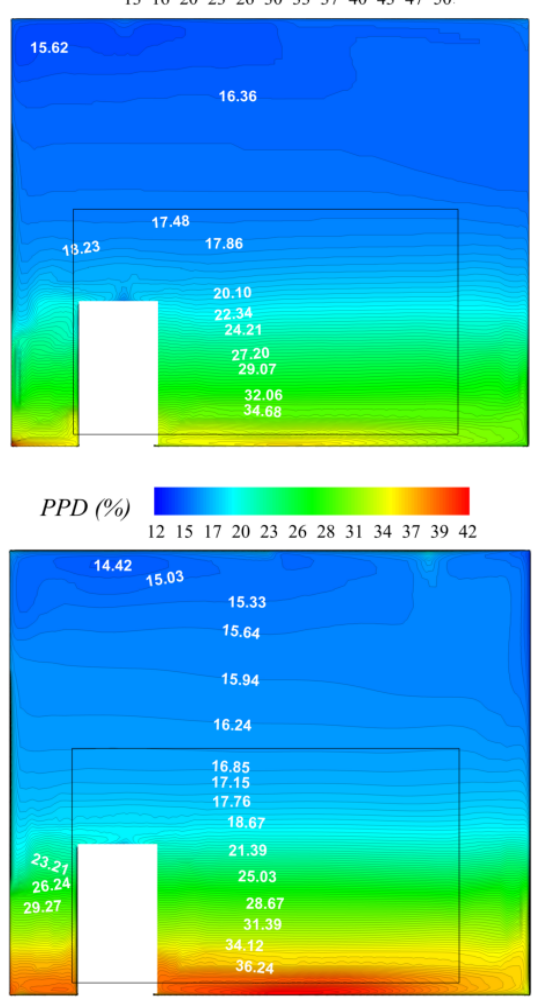

PPD $(\%)$
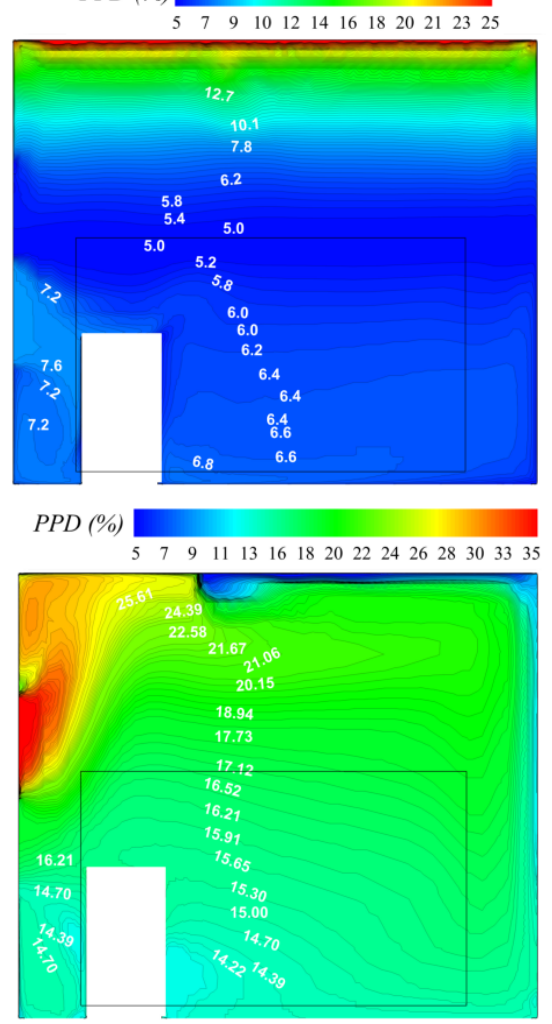

(c)

Figure 9. Spatial distribution of PPD in a vertical cross section passing through the window and occupancy area for the cell office C.O.16 for the (a) reference case, (b) first optimized scenario (c) second optimized scenario. 


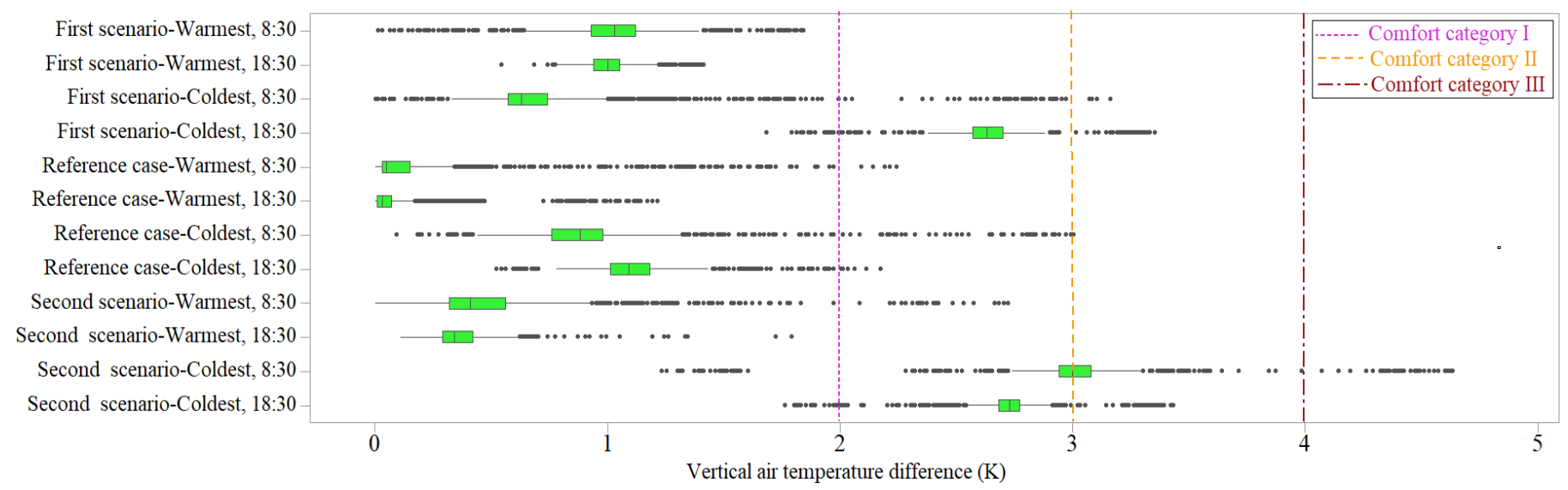

Figure 10. Box plot of vertical air temperature difference between the ankle and head levels for the cell office C.O.16 for different cases.

To analyze the visual comfort in detail for the two optimization scenarios and the reference case, the spatial distribution of three different common dynamic indexes including UDI, cDA, and sDA are shown in Figure 11. Both optimization scenarios showed superior performance compared to the reference case in terms of visual comfort conditions. Concerning the UDI index, more than half of the occupancy area could reach almost 50\% UDI, which is recommended for office buildings [76], after optimization in both scenarios. Nevertheless, the second scenario provided more uniform distribution of relatively high UDI in the entire area during the occupancy hours. This was even more discernible in terms of cDA and sDA indexes (Figure 11b, two bottom rows) so that only a small area near the window could achieve around $35 \%$ sDA during occupancy hours in the first optimization scenario while a larger range of sDA, $30 \%-48 \%$, covered more than $50 \%$ of the whole area. This implies that the combination of shading control method, which adopted indoor temperature and daylight parameters, and window-to-floor ratio could provide better visual comfort quality in the second scenario for the entire year. It is worth mentioning that although a static parameter was considered as the visual comfort constraint $\left(\mathrm{DF}_{\mathrm{avg}}>2 \%\right)$, due to the necessity of Norwegian national requirements, the optimized design variables provided a great improvement in terms of dynamic daylight indexes compared to the reference case. 

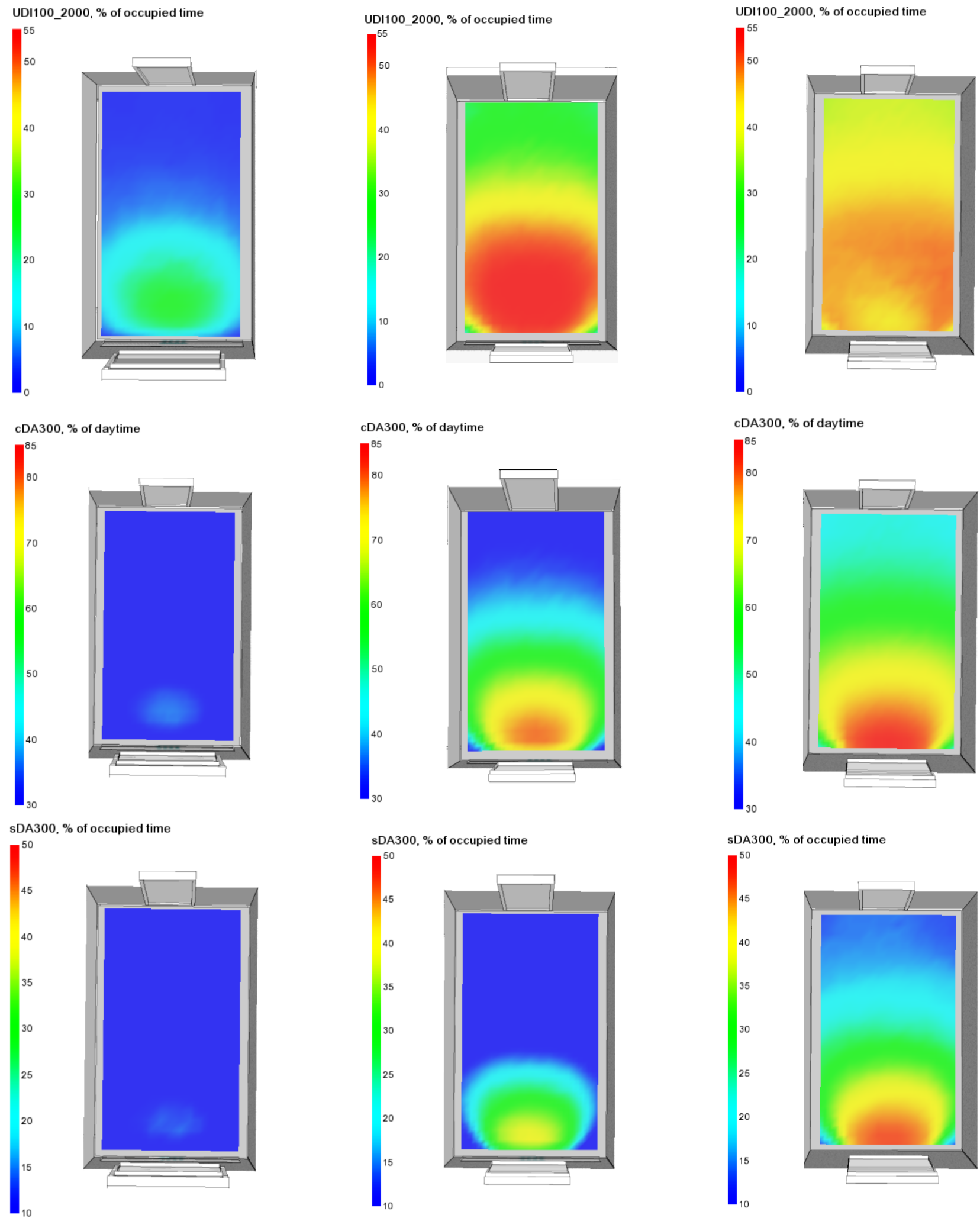

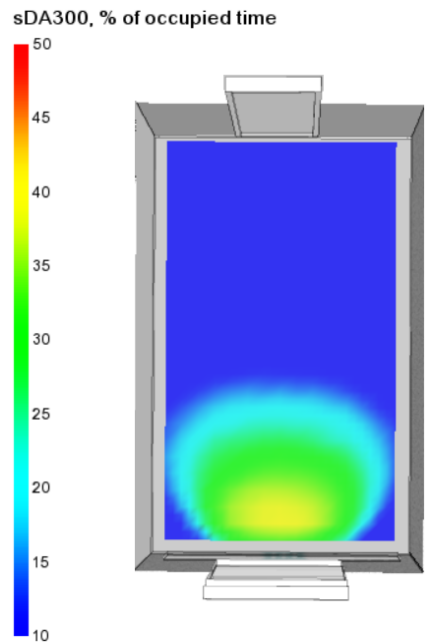

(b)

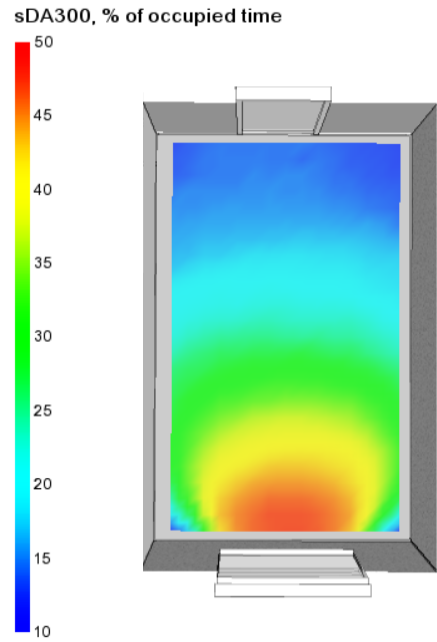

(c)

Figure 11. Spatial distribution of three visual daylight indexes for the cell office C.O.16 for (a) reference case (b) first optimized scenario, and (c) second optimized scenario. 


\section{Conclusions}

In this study, a framework to take advantage of coupling the building energy simulationoptimization process with CFD and daylight simulations was presented. The aim of the proposed framework was to refine the efficiency of feasible studies concerning the retrofitting of building performance.

The objectives were to reduce the building energy use and improve thermal and visual comfort, to be achieved together with the best possible configuration of building envelope, fenestration, shading device and window opening control methods and parameters, and HVAC system set points and control methods. Two different optimization scenarios were considered; (i) a CAV ventilation system with hydronic heating system with radiators and (ii) an all-air system equipped with a DCV system for space heating, space cooling, and ventilation of different zones. The optimization process was carried out using the dynamic building energy simulation software IDA-ICE coupled with GenOpt as the optimization engine. Furthermore, a detailed thermal and visual comfort analysis of all scenarios was conducted through coupling of IDA-ICE with OpenFOAM, which is open source CFD software, and Radiance, which is an open-source daylight simulation engine. This could provide better insights regarding the improvement of thermal and visual comfort throughout the year.

The first part of the results regarding the building energy simulation-optimization (BES-OPT) process revealed that:

- Satisfying thermal comfort requirements was more difficult in an all-air system than in a CAV system during the optimization process. However, as visual comfort was only controlled by window-to-floor ratio and shading device control methods and materials, it was generally more challenging to reach low-level building energy use satisfying visual comfort requirements than thermal comfort conditions.

- The building energy use reduced up to by around $77 \%$ and $79 \%$ in the first and second scenarios respectively while satisfying both thermal and visual comfort.

The second part of the results regarding the detailed thermal comfort and visual comfort analysis are as follows:

- Both optimized scenarios could satisfy thermal comfort requirements, based on comfort category II, for longer periods of the year compared to the reference case, and the second optimized scenario showed the best performance in this respect. However, the DCV system adopted in this scenario could not provide comfortable conditions, according to any of three comfort categories, in extreme cold.

- Concerning the vertical temperature stratifications, most points in the occupancy area met the thermal comfort requirements on the coldest day of the year, which is less than $3 \mathrm{~K}$ according to the second thermal comfort category for office buildings. However, a slight temperature stratification was observed covering around $50 \%$ of the occupancy area at the second scenario in the morning of the coldest day of the year.

- The window opening was functional for both optimized scenarios during summertime and no significant temperature stratification was observed, in spite of using a rather low air flow rate compared to the reference case.

- Regarding the daylight indexes, more than half of the occupancy area could arrive at almost 50\% UDI after optimization in both scenarios. Nevertheless, the second scenario provided more uniform distribution of relatively high UDI in the entire area during the occupancy hours. This was even more discernible in terms of cDA and sDA indexes.

Overall assessment of both BES-OPT process and detailed CFD and daylight analysis proved that the DCV system (all-air system in the second scenario) can be considered as a potential HVAC system in cold climate countries as it can reduce the investment and maintenance costs associated with local space heating and cooling systems. Moreover, the current framework could suggest a paved method for better evaluation of building retrofitting measures through detailed and plausible studies. 
Future developments can also focus on the evaluation of the application of such a method by expanding the possible design variables and objective functions by including the life cycle cost and $\mathrm{CO}_{2}$ footprint of retrofitting measures in the optimization process. In this regard, it is also important to consider the impact of HVAC plant refurbishment in the optimization process as this would have a substantial effect on the total building energy reduction and its corresponding cost and $\mathrm{CO}_{2}$ emissions. Furthermore, the effect of other phenomena such as urban heat island and climate change could be considered in the optimization process as it could have significant impacts on building energy use by increasing space cooling demand and decreasing space heating demand.

Author Contributions: Conceptualization, M.R., H.B.M. and N.N.; methodology, M.R., H.B.M. and N.N.; software, M.R.; validation, M.R.; formal analysis, M.R.; investigation, M.R., H.B.M. and N.N.; writing—original draft preparation, M.R.; writing—review and editing, M.R., H.B.M. and N.N.; supervision, M.R. and N.N.; All authors have read and agreed to the published version of the manuscript.

Funding: This research received no external funding

Institutional Review Board Statement: Not applicable.

Informed Consent Statement: Not applicable.

Conflicts of Interest: The authors declare no conflict of interest.

\section{Appendix A}

The dynamic daylight indexes including UDI, cDA, and sDA were calculated as follows, respectively:

$$
\begin{aligned}
& \mathrm{UDI}\left(\mathrm{Pt}_{\mathrm{i}}\right)=\frac{1}{\mathrm{n}} \sum_{\mathrm{j}=1}^{\mathrm{n}} \mathrm{H}\left(\mathrm{L}\left(\mathrm{Pt}_{\mathrm{i}}, \mathrm{j}\right)\right) \times 100, \mathrm{H}(\mathrm{x})=\left\{\begin{array}{cc}
1 \text { Min } \leq \mathrm{x} \leq \text { Max } \\
0 & \text { out of range }
\end{array}\right\} \\
& \operatorname{cDA}\left(\mathrm{Pt}_{\mathrm{i}}\right)=\frac{1}{\mathrm{~m}} \sum_{\mathrm{j}=1}^{\mathrm{m}} \mathrm{H}\left(\mathrm{L}\left(\mathrm{Pt}_{\mathrm{i}}, \mathrm{j}\right)\right) \times 100, \mathrm{H}(\mathrm{x})=\left\{\begin{array}{cc}
1 & \mathrm{x} \geq \mathrm{L}_{\text {Limit }} \\
\frac{\mathrm{x}}{\mathrm{L}_{\text {Limit }}} & \mathrm{x}<\mathrm{L}_{\text {Limit }}
\end{array}\right\} \\
& \operatorname{sDA}\left(\mathrm{Pt}_{\mathrm{i}}\right)=\frac{1}{\mathrm{n}} \sum_{\mathrm{j}=1}^{\mathrm{n}} \mathrm{H}\left(\mathrm{L}\left(\mathrm{Pt}_{\mathrm{i}}, \mathrm{j}\right)\right) \times 100, \mathrm{H}(\mathrm{x})=\left\{\begin{array}{cc}
1 & \mathrm{x} \geq \mathrm{L}_{\text {Limit }} \\
0 & \mathrm{x}<\mathrm{L}_{\text {Limit }}
\end{array}\right\}
\end{aligned}
$$

where $\mathrm{n}$ and $\mathrm{m}$ referred to total occupancy and daytime hours, respectively. Furthermore, $\mathrm{L}\left(\mathrm{Pt}_{\mathrm{i}}, \mathrm{j}\right)$ represented the daylight simulation results at point $\mathrm{i}\left(\mathrm{Pt}_{\mathrm{i}}\right)$ and time step $\mathrm{j}$, and $\mathrm{H}(\mathrm{x})$ was a function representing the illuminance value.

\section{References}

1. IEA. The Critical Role of Buildings; IEA: Paris, France, 2019; Available online: https:/ /www.iea.org/reports/the-critical-role-ofbuildings (accessed on 10 November 2020).

2. Artola, I.; Rademaekers, K.; Williams, R.; Yearwood, J. Boosting Building Renovation: What Potential and Value for Europe; Study for the iTRE Committee, Commissioned by DG for Internal Policies Policy Department A: Brussels, Belgium, 2016; Volume 72.

3. Directive (EU) 2018/844 of the European parliament and of the council of 30 May 2018 amending Directive 2010/31/EU on the energy performance of buildings and Directive 2012/27/EU on energy efficiency (Text with EEA relevance). Off. J. Eur. Union 2018, 156, 75 .

4. Hashempour, N.; Taherkhani, R.; Mahdikhani, M. Energy performance optimization of existing buildings: A literature review. Sustain. Cities Soc. 2020, 54. [CrossRef]

5. Djuric, N.; Novakovic, V.; Holst, J.; Mitrovic, Z. Optimization of energy consumption in buildings with hydronic heating systems considering thermal comfort by use of computer-based tools. Energy Build. 2007, 39, 471-477. [CrossRef]

6. Rabani, M.; Madessa, H.B.; Mohseni, O.; Nord, N. Minimizing delivered energy and life cycle cost using Graphical script: An office building retrofitting case. Appl. Energy 2020, 268. [CrossRef]

7. Karaguzel, O.T.; Zhang, R.; Lam, K.P. Coupling of whole-building energy simulation and multi-dimensional numerical optimization for minimizing the life cycle costs of office buildings. Build. Simul. 2013, 7, 111-121. [CrossRef] 
8. Chantrelle, F.P.; Lahmidi, H.; Keilholz, W.; Mankibi, M.E.; Michel, P. Development of a multicriteria tool for optimizing the renovation of buildings. Appl. Energy 2011, 88, 1386-1394. [CrossRef]

9. Ferrara, M.; Sirombo, E.; Fabrizio, E. Automated optimization for the integrated design process: The energy, thermal and visual comfort nexus. Energy Build. 2018, 168, 413-427. [CrossRef]

10. Magnier, L.; Haghighat, F. Multiobjective optimization of building design using TRNSYS simulations, genetic algorithm, and Artificial Neural Network. Build. Environ. 2010, 45, 739-746. [CrossRef]

11. Harkouss, F.; Fardoun, F.; Biwole, P.H. Passive design optimization of low energy buildings in different climates. Energy 2018, 165, 591-613. [CrossRef]

12. Asadi, E.; da Silva, M.G.; Antunes, C.H.; Dias, L. A multi-objective optimization model for building retrofit strategies using TRNSYS simulations, GenOpt and MATLAB. Build. Environ. 2012, 56, 370-378. [CrossRef]

13. Niemelä, T.; Levy, K.; Kosonen, R.; Jokisalo, J. Cost-optimal renovation solutions to maximize environmental performance, indoor thermal conditions and productivity of office buildings in cold climate. Sustain. Cities Soc. 2017, 32, 417-434. [CrossRef]

14. Wu, R.; Mavromatidis, G.; Orehounig, K.; Carmeliet, J. Multiobjective optimisation of energy systems and building envelope retrofit in a residential community. Appl. Energy 2017, 190, 634-649. [CrossRef]

15. Hamdy, M.; Hasan, A.; Siren, K. Applying a multi-objective optimization approach for Design of low-emission cost-effective dwellings. Build. Environ. 2011, 46, 109-123. [CrossRef]

16. Palonen, M.; Hamdy, M.; Hasan, A. MOBO a new software for multi-objective building performance optimization. In Proceedings of the BS 2013: 13th Conference of the International Building Performance Simulation Association, Chambery, France, 26-28 August 2013.

17. Mohammadi, Z.; Hoes, P.J.; Hensen, J.L.M. Simulation-based design optimization of houses with low grid dependency. Renew. Energy 2020, 157, 1185-1202. [CrossRef]

18. Zhang, L.; Zhang, L.; Wang, Y. Shape optimization of free-form buildings based on solar radiation gain and space efficiency using a multi-objective genetic algorithm in the severe cold zones of China. Sol. Energy 2016, 132, 38-50. [CrossRef]

19. Kirimtat, A.; Krejcar, O.; Ekici, B.; Fatih Tasgetiren, M. Multi-objective energy and daylight optimization of amorphous shading devices in buildings. Sol. Energy 2019, 185, 100-111. [CrossRef]

20. Fang, Y.; Cho, S. Design optimization of building geometry and fenestration for daylighting and energy performance. Sol. Energy 2019, 191, 7-18. [CrossRef]

21. Naderi, E.; Sajadi, B.; Behabadi, M.A.; Naderi, E. Multi-objective simulation-based optimization of controlled blind specifications to reduce energy consumption, and thermal and visual discomfort: Case studies in Iran. Build. Environ. 2020, 169. [CrossRef]

22. Bassuet, A.; Rife, D.; Dellatorre, L. Computational and Optimization Design in Geometric Acoustics. Build. Acoust. 2014, 21, 75-85. [CrossRef]

23. Saksela, K.; Botts, J.; Savioja, L. Optimization of absorption placement using geometrical acoustic models and least squares. J. Acoust. Soc. Am. 2015, 137, EL274-EL280. [CrossRef]

24. Ferdyn-Grygierek, J.; Grygierek, K. Optimization of Window Size Design for Detached House Using Trnsys Simulations and Genetic Algorithm. Arch. Civ. Eng. Environ. 2018, 10, 133-140. [CrossRef]

25. Delgarm, N.; Sajadi, B.; Delgarm, S. Multi-objective optimization of building energy performance and indoor thermal comfort: A new method using artificial bee colony (ABC). Energy Build. 2016, 131, 42-53. [CrossRef]

26. Schwartz, Y.; Raslan, R.; Mumovic, D. Implementing multi objective genetic algorithm for life cycle carbon footprint and life cycle cost minimisation: A building refurbishment case study. Energy 2016, 97, 58-68. [CrossRef]

27. Delgarm, N.; Sajadi, B.; Kowsary, F.; Delgarm, S. Multi-objective optimization of the building energy performance: A simulationbased approach by means of particle swarm optimization (PSO). Appl. Energy 2016, 170, 293-303. [CrossRef]

28. Arabzadeh, V.; Jokisalo, J.; Kosonen, R. A cost-optimal solar thermal system for apartment buildings with district heating in a cold climate. Int. J. Sustain. Energy 2018, 38, 141-162. [CrossRef]

29. Bamdad, K.; Cholette, M.E.; Guan, L.; Bell, J. Ant colony algorithm for building energy optimisation problems and comparison with benchmark algorithms. Energy Build. 2017, 154, 404-414. [CrossRef]

30. Lu, Y.; Wang, S.; Zhao, Y.; Yan, C. Renewable energy system optimization of low / zero energy buildings using single-objective and multi-objective optimization methods. Energy Build. 2015, 89, 61-75. [CrossRef]

31. Taveres-Cachat, E.; Lobaccaro, G.; Goia, F.; Chaudhary, G. A methodology to improve the performance of PV integrated shading devices using multi-objective optimization. Appl. Energy 2019, 247, 731-744. [CrossRef]

32. Yi, Y.K. Building facade multi-objective optimization for daylight and aesthetical perception. Build. Environ. 2019, 156, 178-190. [CrossRef]

33. Tommasi, L.D.; Ridouane, H.; Giannakis, G.; Katsigarakis, K.; Lilis, G.N.; Rovas, D. Model-Based Comparative Evaluation of Building and District Control-Oriented Energy Retrofit Scenarios. Buildings 2018, 8, 91. [CrossRef]

34. García-Fuentes, M.A.; Hernández, G.; Serna, V.; Martín, S.; Álvarez, S.; Lilis, G.N.; Giannakis, G.; Katsigarakis, K.; Mabe, L.; Oregi, X.; et al. OptEEmAL: Decision-Support Tool for the Design of Energy Retrofitting Projects at District Level. IOP Conf. Ser. Earth Environ. Sci. 2019, 290, 012129. [CrossRef]

35. Hirvonen, J.; Jokisalo, J.; Heljo, J.; Kosonen, R. Towards the EU emissions targets of 2050: Optimal energy renovation measures of Finnish apartment buildings. Int. J. Sustain. Energy 2019, 38, 649-672. [CrossRef] 
36. Hong, T.; Kim, J.; Lee, M. A multi-objective optimization model for determining the building design and occupant behaviors based on energy, economic, and environmental performance. Energy 2019, 174, 823-834. [CrossRef]

37. Pazouki, M.; Rezaie, K.; Bozorgi-Amiri, A. A fuzzy robust multi-objective optimization model for building energy retrofit considering utility function: A university building case study. Energy Build. 2021, 241, 110933. [CrossRef]

38. Lu, S.; Li, J.; Lin, B. Reliability analysis of an energy-based form optimization of office buildings under uncertainties in envelope and occupant parameters. Energy Build. 2020, 209, 109707. [CrossRef]

39. Karmellos, M.; Kiprakis, A.; Mavrotas, G. A multi-objective approach for optimal prioritization of energy efficiency measures in buildings: Model, software and case studies. Appl. Energy 2015, 139, 131-150. [CrossRef]

40. Caldas, L.; Santos, L. Painting with light: An interactive evolutionary system for daylighting design. Build. Environ. 2016, 109, 154-174. [CrossRef]

41. Sameti, M.; Haghighat, F. Optimization approaches in district heating and cooling thermal network. Energy Build. 2017, 140, 121-130. [CrossRef]

42. Chegari, B.; Tabaa, M.; Simeu, E.; Moutaouakkil, F.; Medromi, H. Multi-objective optimization of building energy performance and indoor thermal comfort by combining artificial neural networks and metaheuristic algorithms. Energy Build. 2021, 239, 110839. [CrossRef]

43. Foucquier, A.; Robert, S.; Suard, F.; Stéphan, L.; Jay, A. State of the art in building modelling and energy performances prediction: A review. Renew. Sustain. Energy Rev. 2013, 23, 272-288. [CrossRef]

44. Axley, J. Multizone Airflow Modeling in Buildings: History and Theory. HVACER Res. 2007, 13, 907-928. [CrossRef]

45. Tian, W.; Sevilla, T.A.; Zuo, W.; Sohn, M.D. Coupling fast fluid dynamics and multizone airflow models in Modelica Buildings library to simulate the dynamics of HVAC systems. Build. Environ. 2017, 122, 269-286. [CrossRef]

46. Crawley, D.B.; Hand, J.W.; Kummert, M.; Griffith, B.T. Contrasting the capabilities of building energy performance simulation programs. Build. Environ. 2008, 43, 661-673. [CrossRef]

47. Nielsen, P.V. Fifty years of CFD for room air distribution. Build. Environ. 2015, 91, 78-90. [CrossRef]

48. Nielsen, P.V.; Allard, F.; Awbi, H.B.; Davidson, L.; Schälin, A. Computational Fluid Dynamics in Ventilation Design REHVA guidebook No 10. Int. J. Vent. 2007, 6, 291-294. [CrossRef]

49. Novoselac, A. Combined Airflow and Energy Simulation Program for Building Mechanical System Design. Ph.D. Thesis, The Pennsylvania State University, State College, PA, USA, 2004.

50. Tian, W.; Han, X.; Zuo, W.; Sohn, M.D. Building energy simulation coupled with CFD for indoor environment: A critical review and recent applications. Energy Build. 2018, 165, 184-199. [CrossRef]

51. Rodríguez-Vázquez, M.; Hernández-Pérez, I.; Xamán, J.; Chávez, Y.; Gijón-Rivera, M.; Belman-Flores, J.M. Coupling building energy simulation and computational fluid dynamics: An overview. J. Build. Phys. 2020, 44, 137-180. [CrossRef]

52. Shan, X.; Luo, N.; Sun, K.; Hong, T.; Lee, Y.-K.; Lu, W.-Z. Coupling CFD and Building Energy Modelling to Optimize the Operation of a Large Open Office Space for Occupant Comfort. Sustain. Cities Soc. 2020. [CrossRef]

53. Pandey, B.; Banerjee, R.; Sharma, A. Coupled EnergyPlus and CFD analysis of PCM for thermal management of buildings. Energy Build. 2021, 231, 110598. [CrossRef]

54. Yamamoto, T.; Ozaki, A.; Lee, M.; Kusumoto, H. Fundamental study of coupling methods between energy simulation and CFD. Energy Build. 2018, 159, 587-599. [CrossRef]

55. Colombo, E.; Zwahlen, M.; Frey, M.; Loux, J. Design of a glazed double-façade by means of coupled CFD and building performance simulation. Energy Procedia 2017, 122, 355-360. [CrossRef]

56. Zhang, R.; Mirzaei, P.A. Fast and dynamic urban neighbourhood energy simulation using CFDf-CFDc-BES coupling method. Sustain. Cities Soc. 2021, 66, 102545. [CrossRef]

57. Björsell, N.; Bring, A.; Eriksson, L.; Grozman, P.; Lindgren, M.; Sahlin, P.; Shapovalov, A.; Vuolle, M. IDA indoor climate and energy. In Proceedings of the 6-th IBPSA Conference, Kyoto, Japan, 13-15 September 1999; pp. 1035-1042.

58. OpenFOAM Foundation. 2018. Available online: https://github.com/OpenFOAM/OpenFOAM-dev (accessed on 20 October 2020).

59. Statistics Norway. 2019. Available online: https://www.ssb.no/en/bygg-bolig-og-eiendom/statistikker/bygningsmasse/aar (accessed on 30 December 2019).

60. Byggeforskrift-TEK 87, 1987. Available online: https://dibk.no/globalassets/byggeregler/tidligere_regelverk/historisk-arkiv-19 49---1987/byggeforskrift-1987.pdf (accessed on 15 November 2020).

61. Rabani, M.; Bayera Madessa, H.; Nord, N. Achieving zero-energy building performance with thermal and visual comfort enhancement through optimization of fenestration, envelope, shading device, and energy supply system. Sustain. Energy Technol. Assess. 2021, 44, 101020. [CrossRef]

62. Standard Norge. NS-3701-Criteria for Passive Houses and Low Energy Buildings, Non-Residential Buildings, 2012; Standard Norge: Oslo, Norway, 2012.

63. Arbeidstilsynet. Available online: https://www.arbeidstilsynet.no/tema/utforming-av-arbeidsplassen/rad-ved-tilbakeforingtil-arbeid-for-kontorarbeidsplasser/ (accessed on 15 November 2020). 
64. The Director General of the National Archival Services of Norway, Requirements for Archive Premises-Guidelines for Public Bodies, 2007. Available online: https:/ / www.arkivverket.no/om-oss/vare-publikasjoner/riksarkivarens-rapporter-og-retningslinjer/_/ attachment/download/04cc2705-d572-41e7-8810-a6e4f19f5f31:d24e6e9c694a8dc844695d015e544baea21e4351/Requirements\%20 for\%20archive\%20premises.pdf (accessed on 15 November 2020).

65. Building Technical Regulations (TEK17) 2017, § 14-2. Requirements for Energy Efficiency. Available online: https:/ /dibk.no/ regelverk/byggteknisk-forskrift-tek17/14/14-2/ (accessed on 13 April 2021). (In Norwegian).

66. NS-15251-2014, Indoor Environmental Input Parameters for Design and Assessment of Energy Performance of Buildings Addressing Indoor Air Quality, Thermal Environment, Lighting and Acoustics; Standard Norge: Oslo, Norway, 2014.

67. Wetter, M. GenOpt (R), Generic Optimization Program, User Manual, Version 2.0.0; Lawrence Berkeley National Laboratory: Berkeley, CA, USA, 2003.

68. Ward, G.; Shakespeare, R. Rendering with Radiance: The art and science of lighting visualization; Morgan Kaufmann Publishers: San Francisco, CA, USA, 1998.

69. Rabani, M.; Madessa, H.B.; Nord, N.; Schild, P.; Mysen, M. Performance assessment of all-air heating in an office cubicle equipped with an active supply diffuser in a cold climate. Build. Environ. 2019, 156, 123-136. [CrossRef]

70. Cablé, A.; Mysen, M.; Thunshelle, K. Can demand controlled ventilation replace space heating in office buildings with low heating demand? In Proceedings of the 2014-13th Indoor Air Conference, Hong Kong, China, 7-12 July 2014.

71. van Hooff, T.; Nielsen, P.V.; Li, Y. Computational fluid dynamics predictions of non-isothermal ventilation flow-How can the user factor be minimized? Indoor Air 2018, 28, 866-880. [CrossRef] [PubMed]

72. Nabil, A.; Mardaljevic, J. Useful daylight illuminance: A new paradigm for assessing daylight in buildings. Light. Res. Technol. 2005, 37, 41-57. [CrossRef]

73. Rogers, Z.; Goldman, D. Daylighting Metric Development Using Daylight Autonomy Calculations in the Sensor Placement Optimization Tool; Architectural Energy Corporation: Boulder, CO, USA, 2006; Available online: http://www.archenergy.com/SPOT/SPOT_ Daylight\%20Autonomy\%20Report.pdf (accessed on 15 November 2020).

74. LM, I. Approved Method: IES Spatial Daylight Autonomy (sDA) and Annual Sunlight Exposure (ASE); IES Standard LM-83-12; Illuminating Engineering Society of North America: New York, NY, USA, 2012.

75. NS-EN ISO 7730-2006. Ergonomics of the Thermal Environment-Analytical Determination and Interpretation of Thermal Comfort Using Calculation of the PMV and PPD Indices and Local Thermal Comfort Criteria; Standard Norge: Oslo, Norway, 2006.

76. Reinhart, C.F.; Weissman, D.A. The daylit area-Correlating architectural student assessments with current and emerging daylight availability metrics. Build. Environ. 2012, 50, 155-164. [CrossRef] 